Article

\title{
An Integrated Approach to a Nitrogen Use Efficiency (NUE) Indicator for the Food Production-Consumption Chain
}

\author{
Jan Willem Erisman ${ }^{1,2, *(\mathbb{D})}$, Allison Leach ${ }^{3}$, Albert Bleeker ${ }^{4,+}{ }^{(1)}$, Brooke Atwell $^{5}$, Lia Cattaneo ${ }^{5}$ \\ and James Galloway 5 (i) \\ 1 Louis Bolk Institute, Driebergen 3972LA, The Netherlands \\ 2 Faculty of Science, Earth and Climate, VU University, Amsterdam 1081HV, The Netherlands \\ 3 Department of Natural \& The Environment and The Sustainability Institute, University of New Hampshire, \\ Durham, NH 03824, USA; Allison.Leach@unh.edu \\ 4 Energy Research Center of the Netherlands, Petten 1755LE, The Netherlands; albert.bleeker@pbl.nl \\ 5 Department of Environmental Science, University of Virginia, Charlottesville, VA 22904, USA; \\ bea4vq@virginia.edu or brooke.atwell77@gmail.com (B.A.); lrc4yd@virginia.edu (L.C.); \\ jng@eservices.virginia.edu (J.G.) \\ * Correspondence: j.w.erisman@vu.nl; Tel.: +31-343-523-860 \\ † Current address: PBL Netherlands Environmental Assessment Agency, The Hague 2594AV, \\ The Netherlands.
}

Received: 13 December 2017; Accepted: 20 March 2018; Published: 22 March 2018

\begin{abstract}
Reducing nitrogen pollution across the food chain requires the use of clear and comprehensive indicators to track and manage losses. The challenge is to derive an easy-to-use robust nitrogen use efficiency (NUE) indicator for entire food systems to help support policy development, monitor progress and inform consumers. Based on a comparison of four approaches to NUE (life cycle analysis, nitrogen footprint, nitrogen budget, and environmental impact assessment), we propose an indicator for broader application at the national scale: The whole food chain $\left(\mathrm{NUE}_{\mathrm{FC}}\right)$, which is defined as the ratio of the protein (expressed as nitrogen) available for human consumption to the (newly fixed and imported) nitrogen input to the food system. The $\mathrm{NUE}_{\mathrm{FC}}$ was calculated for a set of European countries between 1980 and 2011. A large variation in $\mathrm{NUE}_{\mathrm{FC}}$ was observed within countries in Europe, ranging from $10 \%$ in Ireland to $40 \%$ in Italy in 2008 . The NUE $\mathrm{FC}_{\mathrm{FC}}$ can be used to identify factors that influence it (e.g., the share of biological nitrogen fixation (BNF) in new nitrogen, the imported and exported products and the consumption), which can be used to propose potential improvements on the national scale.
\end{abstract}

Keywords: nitrogen use efficiency; food chain; Europe; budget

\section{Introduction}

Nitrogen $(\mathrm{N})$ is a key nutrient, vital for the survival of humans and all other living organisms. While di-nitrogen gas $\left(\mathrm{N}_{2}\right)$ is abundant in the atmosphere, most organisms are unable to use this chemically unreactive form. First it must be converted or "fixed" into a reactive form such as ammonia $\left(\mathrm{NH}_{3}\right)$ or nitrogen oxide $\left(\mathrm{NO}_{\mathrm{x}}\right)$. This and other forms of reactive nitrogen (all forms of nitrogen other than the inert atmospheric $\mathrm{N}_{2}$ gas; $\mathrm{N}_{\mathrm{r}}$ ) are comparatively scarce and represent a limiting resource in most ecosystems and in farmlands (e.g., [1] and references therein).

By the end of the 19th century, the natural sources of fixed nitrogen were not sufficient for the food production needs of a rapidly increasing human population in Western Europe. The development and adoption of the Haber-Bosch process enabled widespread production and use of synthetic N-fertilizers, 
leading to a dramatic increase in agricultural productivity. This holds for both crop production and livestock production, the latter as the result of increased feed availability. The growth in livestock production, the specialization and agglomeration of livestock production systems, and the poor management of manure nitrogen contributed to low efficiency of nitrogen use in the food system [2]. Because of the generally low nitrogen fertilizer use efficiency of agriculture, much of industrially fixed nitrogen is eventually released into the biosphere. The burning of fossil fuels also releases large amounts of nitrogen oxide emissions into the atmosphere. Because of these releases, and the fact that the world converts more nitrogen from the atmosphere into reactive forms through anthropogenic processes than all of the Earth's natural processes in terrestrial systems combined, the global nitrogen cycle has been dramatically altered-even more than the global carbon cycle [3,4].

The negative consequences of this human-generated change are becoming ever more apparent. Numerous, often interlinked, thresholds for human and ecosystem health have been exceeded due to excess reactive nitrogen pollution, including thresholds for drinking water quality (due to nitrates) and air quality (smog, particulate matter, ground-level ozone). Eutrophication of freshwater and coastal ecosystems (i.e., dead zones), climate change and stratospheric ozone depletion are also consequences of the human modified $\mathrm{N}_{\mathrm{r}}$ cycle. Each of these environmental effects can be magnified by a 'nitrogen cascade' whereby a single atom of reactive nitrogen can trigger a sequence of negative environmental impacts through time and space (e.g., [1,4-6]).

Management of $\mathrm{N}$ resources is important, especially in food production, as agriculture is the biggest user of anthropogenic $\mathrm{N}$ in the world. The negative impacts of $\mathrm{N}$ due to our food production are caused by a general decrease in the nitrogen use efficiency (NUE) in most regions of the world (e.g., [7]). NUE is defined by the Organisation for Economic Co-operation and Development (OECD) as the ratio between the amount of fertilizer $\mathrm{N}$ removed from the field by the crop and the amount of fertilizer $\mathrm{N}$ applied. Here we expand NUE for the whole food system as the ratio of the amount of nitrogen available for food consumption of the new nitrogen used for the production of that food. N management in agriculture should aim at achieving agronomic, economic, social and environmental objectives. This requires solid data and information about $\mathrm{N}$ flows in relation to sustainability and tools and key performance indicators to support management, policies, decisions and actions. Indicators play a key role in management and policy; they should have a solid scientific and analytical basis and should be defined in a uniform and reproducible manner [8]. There are many studies that focus on the farm-level, crop or housing system NUE. However, these are less suitable for policy application on a national level.

The aim of this paper is to develop a NUE indicator for the whole food system in order to understand the NUE for the whole food production-consumption chain to help policy makers develop strategies for a more nitrogen-efficient food production, to minimise losses in the food system and to help elucidate where the efficiency is lowest in the chain and thus where optimization is possible to increase NUE. This action will help policymakers and consumers influence consumption patterns and encourage the consumption of products that contain the most $\mathrm{N}$ (i.e., protein) but require the lowest $\mathrm{N}$ inputs.

Here we therefore focus on the NUE indicator for the whole food system, which goes beyond the farm level NUE indicator (Figure 1: until 'food industry'), taking into account processing and distribution (Figure 1: Food industry). The NUE indicator for the whole food chain, $\mathrm{NUE}_{\mathrm{FC}}$, is defined as the available food for consumption of protein $\mathrm{N}$ (protein in food available) for a given human population divided by the newly formed $\mathrm{N}$ that was used to produce the food. This full-chain NUE therefore describes the percent of nitrogen invested in food production that is contained in the final consumed food product. It provides a measure about how effectively the new reactive nitrogen created for food production is converted into the food protein $\mathrm{N}$ available for consumption. 


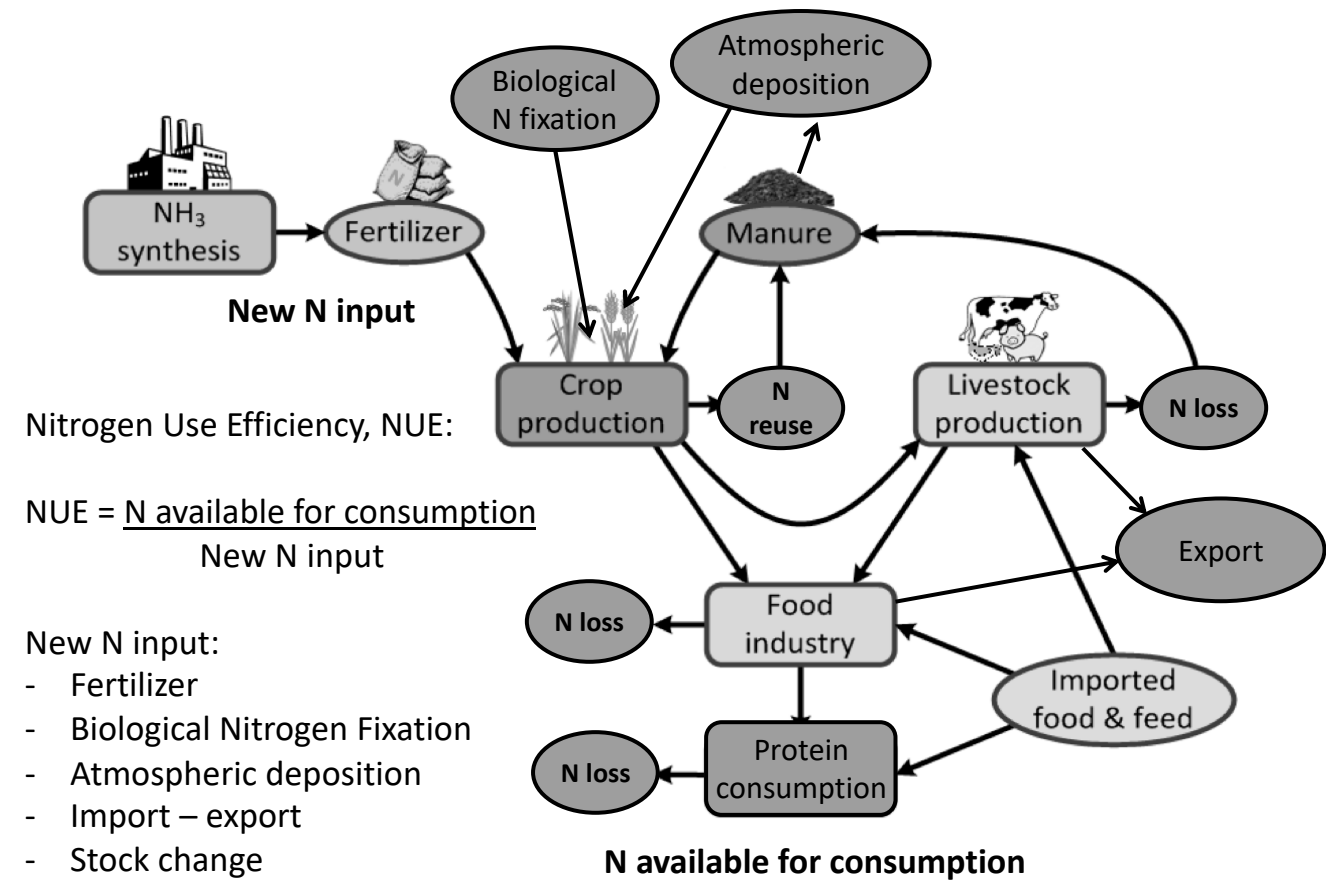

Figure 1. The major components of the full-chain nitrogen use efficiency ( $\mathrm{NUE}_{\mathrm{FC}}$ ) in the national food system. This figure also shows where losses (noted as "N-loss", not being reused) occur that reduce the efficiency. Up to the 'Food industry' box, the interactions are as represented by EU Nitrogen Expert Panel [8] in the agricultural system.

There are several methods available to determine the NUEFC. These methods have different aims, system bounds, limitations and advantages when used as a basis for deriving the full-chain NUE. We provide a review of these methods and indicators for NUE with the aim of proposing one (or a more coherent set of) indicator(s) for NUE in the whole food system in Europe (EU28) and its constituent countries, including an assessment of the advantages and disadvantages, the limitations, data availability and potential use.

The aims are to provide:

(i) A literature review of existing indicators for full-chain NUE in the food production-consumption chain at the national and/or regional scales in European countries;

(ii) A proposal for one indicator or a coherent set of indicators for NUE in the food system in Europe at the national or regional levels, which is 'linked' to the general concept agreed upon during the first meeting of the panel (EU Nitrogen Expert Panel, 2014), and which can be used by policymakers and practitioners in Europe (industry, consumers, NGOs, policy, research); and

(iii) A demonstration of the use of the proposed indicator using European national data sets and a discussion of its usability.

\section{Literature Review: Approaches to Estimating NUE}

Four approaches are commonly used to assess nitrogen use efficiencies of food production-consumption and/or the environmental impact of $\mathrm{N}$ use in food production: life cycle analysis, nitrogen footprint analysis, nitrogen budget analysis, and environmental impact assessment. These approaches are briefly described below, with more detailed information given in the Supplementary Material (SM). The four approaches distinguished are not equally specific for estimating NUE, but they do provide information about the $\mathrm{N}$ use and possible environmental impacts of the $\mathrm{N}$ use. The four approaches are: 
(i) Life Cycle Analysis (LCA): A technique to assess the potential environmental and human health impacts associated with a product, process, or service by: (1) compiling an inventory of relevant energy and material inputs and environmental releases and (2) evaluating the potential environmental impacts associated with the identified inputs and releases (e.g., [9-18] (See Appendix ??, Table A1).

(ii) Nitrogen Footprint: Total $\mathrm{N}$ losses to the environment resulting from the production of a defined unit of food (e.g., [19-25] (See Appendix ??, Table A2).

(iii) Nitrogen Budget: The inputs and outputs of nitrogen across the boundaries of a system. Can contain information about internal nitrogen fluxes within the system (e.g., $[1,26-37])$. The farm-gate nitrogen budget is a common indicator for assessing the total inputs and outputs across a farm's boundaries. The nitrogen balance indicator measures the difference between the nitrogen available to an agricultural system and the nitrogen harvested and exported from the system in agricultural products. The food system waste/loss indicator: this category has received special attention by studies that estimate the loss of $\mathrm{N}$ through waste [38-40] (See Appendix ??, Table A3).

(iv) Environmental Impact Assessment: A process of evaluating the likely environmental impacts of a proposed project or development, taking into account inter-related socio-economic, cultural, and human health impacts both beneficial and adverse (e.g., [41-43] (See Appendix ??, Table A4).

A literature review was conducted of the aforementioned approaches, and a total of 36 peer-reviewed studies were identified and categorized according to approach, country, and product as displayed in Appendix ??. The different studies cover 17 products and 30 countries. Of the papers collected, 11 used the LCA approach, six used the $\mathrm{N}$ footprint approach, 16 used the $\mathrm{N}$ budget approach, and three used the EIA approach.

All four approaches are useful for the purpose they serve. The level of detail varies and depends on the goal of the study as well as the availability of data. However, the $\mathrm{N}$ budget analysis approach is most suitable for estimating $\mathrm{NUE}_{\mathrm{FC}}$; this approach allows the direct estimation/derivation of NUE, $\mathrm{N}$ outputs and $\mathrm{N}$ surplus.

\section{Literature Values}

There were several studies that calculated the $\mathrm{NUE}_{\mathrm{FC}}$ for a country or a region for all food production using the budget method:

- Norway: $10 \%([26])$

- Germany: $10 \%$ ([44])

- USA: $15 \%$ for plant protein and 5\% animal protein ([29])

- Global: $4 \%$ for meat and $14 \%$ for plant production ([28])

- Europe: $18 \%([45])$

- China: $9 \%$ ([33])

World: country ranges from 1\% (Mongolia) and 4\% (Australia) to 106\% (Nepal) and $112 \%$ (Rwanda), where nitrogen mining takes place ([7]).

These studies show that the overall full-chain $\mathrm{N}$ efficiency ( $\mathrm{NUE}_{\mathrm{FC}}$ ) is between 5 and $15 \%$, which is a fairly small range. This means that on average, only $5-15 \%$ of the nitrogen invested in global food production is contained in final consumed food products. In some regions, the estimated NUEFC was very high (even more than $100 \%$; Sutton et al. [7]), probably due to soil $\mathrm{N}$ mining.

\section{Selection of Approach}

The four full-chain approaches have strengths and weaknesses (Table 1). These strengths and weaknesses form the basis for our selection of a recommended approach for estimating full chain NUE. Other criteria include the feasibility of linking to the farm-scale NUE indicator, the system boundaries, 
and the current and foreseen data availability. The system boundaries defined here are set by the food system. This means that the energy and transport part of the food chain will not be included. However, the atmospheric deposition resulting from these $\mathrm{N}$ emission sources is included, similar to the study by the EU Nitrogen Expert Panel [8].

The LCA approach provides an established framework for detailed calculation of the $\mathrm{N}$ flows and losses to the environment in the different steps of the food system. Detailed data are needed for this approach. Although LCA has been completed for some food products in Europe, it is clear that the data needed for all European countries and products will not be available in the near future for a complete analysis of the whole food chain for all countries. Recently, Leip et al. [32] used the LCA approach together with the CAPRI (Common Agricultural Policy Regionalised Impact) model to estimate the $\mathrm{N}$ losses and impacts of livestock in Europe.

The $\mathrm{N}$ footprint and $\mathrm{N}$ budget approaches both use $\mathrm{N}$ input and output balances. The $\mathrm{N}$ footprint approach also considers $\mathrm{N}$ losses at each stage of the food production process, whereas the $\mathrm{N}$ budget looks at overall inputs and outputs for a given system. Given this, the $\mathrm{N}$ footprint approach is generally more data-intensive than the $\mathrm{N}$ budget approach. In addition, the $\mathrm{N}$ budget approach can be more easily applied at multiple scales (e.g., a step of the food system, an individual product, farm, region, country) given its flexibility in assigning the system bounds.

LCA and EIA both integrate environmental impact assessment; the other approaches simply assess $\mathrm{N}$ emissions to the environment. Impacts are region and climate specific; comparison of food systems based on impacts is therefore difficult. Furthermore, directly linking $\mathrm{N}$ use to the impact of $\mathrm{N}$ use is not part of the objective of 'how to estimate NUE of the food chain'.

In summary, most approaches for estimating $\mathrm{N}$ use in the food chain assess the losses of $\mathrm{N}$ from the food system and some link these losses to the environmental impacts (life cycle analysis, $\mathrm{N}$-Footprint, environmental impact assessment). The $\mathrm{N}$ budget approach, by contrast, compares the overall inputs and outputs of a system. The focus on losses for the step-by-step approaches (LCA, N-Footprint, EIA) is less useful for calculating NUE, because NUE is based on the balance between N supply and the $\mathrm{N}$ in a final product. Furthermore, the different approaches should provide comparable results when applied to the same system since $\mathrm{N}$ supply should be the same as (the total $\mathrm{N}$ input-total $\mathrm{N}$ loss), provided all the $\mathrm{N}$ losses are known (including denitrification).

The N-budgeting approach is most useful for estimating the whole food system NUE, because it aligns better with the application objectives and the data required for its calculation are readily available. Nitrogen budget approaches compile the inputs and outputs of nitrogen across the boundaries of a system in order to model and quantify internal nitrogen fluxes by using a mass-balance approach. This approach captures all $\mathrm{N}$ in all the relevant steps throughout the food system and it can be applied to a range of products and locations with readily available international data sets. 
Table 1. Advantages and disadvantages of four different full-chain nitrogen use efficiency approaches: life cycle analysis, nitrogen footprint, nitrogen budget, and environmental impact assessment.

\begin{tabular}{|c|c|c|c|c|c|c|c|c|c|c|c|c|c|}
\hline & \multicolumn{7}{|c|}{ Advantages } & \multicolumn{6}{|c|}{ Disadvantages } \\
\hline & $\begin{array}{c}\text { Links to } \\
\text { Environmental } \\
\text { Impacts }\end{array}$ & $\begin{array}{l}\text { Can Account } \\
\text { for Trade }\end{array}$ & $\begin{array}{l}\text { Flexible System } \\
\text { Boundaries }{ }^{1}\end{array}$ & $\begin{array}{l}\text { Models Internal } \\
\text { N Fluxes }\end{array}$ & $\begin{array}{l}\text { Socio-Economic, } \\
\text { Cultural, and } \\
\text { Health Impacts }{ }^{2}\end{array}$ & $\begin{array}{l}\text { Can Account for } \\
\text { Recycled and } \\
\text { New N }\end{array}$ & $\begin{array}{l}\text { Mass Flow } \\
\text { Model }^{3}\end{array}$ & $\begin{array}{c}\text { Data } \\
\text { Intensive } \\
\end{array}$ & $\begin{array}{l}\text { Inconsistent } \\
\text { Allocation } \\
\text { Methods }\end{array}$ & $\begin{array}{c}\text { Difficult to } \\
\text { Compare } \\
\text { Impacts } \\
\end{array}$ & $\begin{array}{l}\text { Regional Level } \\
\text { and Above }\end{array}$ & Site-Specific & $\begin{array}{l}\text { Indeterminable } \\
\text { Fate of System } \\
\text { Outputs } 5\end{array}$ \\
\hline $\begin{array}{c}\text { Life Cycle } \\
\text { Analysis }\end{array}$ & $x$ & & $x$ & & $x$ & & & $x$ & $x$ & $x$ & & $x$ & \\
\hline N Budget & & $x$ & $x$ & $x$ & & & $x$ & & $x$ & & $x$ & & $x$ \\
\hline $\begin{array}{l}\text { Environmental } \\
\text { Impact } \\
\text { Assessment }\end{array}$ & $x$ & & $x$ & & $x$ & & & $x$ & $x$ & $x$ & & $x$ & \\
\hline
\end{tabular}

${ }^{1}$ In most cases, the system boundaries are not predetermined and can be established to accommodate data gaps and the study objectives; 2 Some $\mathrm{N}$ indicator models have the ability to link to environmental, health and socio-economic impacts, which can be advantageous when used to inform policy; ${ }^{3}$ The terminology 'mass flow model' represents all balance equations that can be used to calculate intermediary stages. This is useful when quantifying flows that cannot be directly measured; 4 When linking a study to its environmental effects, it is not yet possible to objectively compare and contrast across impacts. To this point, one cannot definitively rank 'products' according to their level of sustainability, and impacts are usually measured on a regional basis, so cannot be scaled up without expanding the system boundaries; 5 e.g., leaching vs. denitrification. 


\section{Definition of a Full-Chain NUE (NUE $\mathrm{FC})$}

A food system can be regarded as a chain of sectors and activities: the producers, the collectors, the processors, the distributors, the retailers and the consumers. Within each sector, activities reduce the amount of $\mathrm{N}$ that makes it to the next stage of food production, e.g., through food waste or other losses to the environment. The result is that the total amount of $\mathrm{N}$ embodied in the product decreases with each step. For a particular food system, a distinction is often made between the production of plant and animal protein (e.g., [20]). Animal protein production adds other steps to the cycle and introduces the recycling of manure. Since nutrition is the essence of food, to achieve a maximum $\mathrm{NUE}_{\mathrm{FC}}$, the Consumed $\mathrm{N}$ should be as high as possible and the New $\mathrm{N}$ as low as possible. The NUE for each step in the food chain (Figure 1) is defined as Consumed N (the outputs) divided by New N (the inputs). For each step in each 'sector', a ratio can be derived, which represents the efficiency of the sector in terms of $\mathrm{N}$ use, e.g., Edible crop N/Crop N, which represents the efficiency of the processing of crops.

In order to calculate the NUE for the whole food system using the budgeting approach, the use of $\mathrm{N}$ in the system has to be estimated. The amount of $\mathrm{N}$ of each sector (Figure 1) is needed to calculate the associated NUE of that sector. One complicating aspect is that NUE is influenced by the import and export of food and feed. These trade flows have to be included in the equation, as NUEFC represents the NUE of the entire food system. NUE $\mathrm{FC}_{\mathrm{FC}}$ is defined as follows:

$$
\mathrm{NUE}_{\mathrm{FC}}=\frac{\mathrm{N} \text { food availability }}{\text { fertilizer }+\mathrm{BNF}+\text { atm. dep }+ \text { (import }- \text { export })+ \text { changes in stock }}
$$

Here ' $\mathrm{N}$ food availability' (consumption) is usually determined by the $\mathrm{N}$ supplied to the households.

This equation includes $\mathrm{N}$ inputs to agricultural systems via the atmospheric deposition of non-agricultural sources (fossil-fuel-based emissions) and not the total $\mathrm{N}$ deposition and not the entire country (total surface area). The major components of $\mathrm{NUE}_{\mathrm{FC}}$ are shown in Figure 1. The net import (import-export) was used instead of placing 'export' in the denominator and 'import' in the nominator, because for countries where import and export are very high (throughput) this influences the efficiency. In the ideal case, the NUE for the imported products should be taken into account, but because of lack of data this is not included. The same holds for the exported products. In Equation (1) 'change in stock' is the annual net balance of the imports and exports of a country, which includes the storage of products. This term is zero over the long-term, but can be significant for a single year. Since we are focussing here on the national level, we assume that internal cycling of nitrogen within the country does not affect the NUE when using country-scale production and food availability.

The equation above defines the NUE over the whole food system, but it can be split into different parts, such as food processing, the agricultural system, or the consumer whenever data are available. NUE is represented by the agricultural system NUE as defined by the EU Nitrogen Expert Panel [8].

The data needed for the country level are listed in Table 2. With the data available in Europe, the country level can be calculated using the FAO Food Balance Sheets for protein consumption (availability of food), while for all commodities the $\mathrm{N}$ content was taken from [31] to obtain the total food N supply (N Consumed). Further, fertilizer statistics may be obtained from Fertilizers Europe (through the European Statistical Office-EUROSTAT), biological nitrogen fixation (BNF) from [46], or more recently from [31], and atmospheric deposition to agricultural lands from the European Monitoring and Evaluation Programme (EMEP) [47]. In addition, Edible crop N, Vegetable N and Consumed $\mathrm{N}$ for crops are needed, and data for animal protein food availability, which are available from the statistical database of the Food and Agriculture Organization (FAOSTAT). Furthermore, data on the import and export of feed, plant and animal protein are available from the FAO statistics. 
Table 2. Overview of data that are needed for the country-level approach for calculating nitrogen use efficiency with a nitrogen budget approach.

\begin{tabular}{|c|c|c|}
\hline Part of NUE & Specific Flow/Part of NUE & Country Level Data Source \\
\hline \multirow{5}{*}{ New $N$} & Fertilizer & $\begin{array}{l}\text { Fertilizer application per crop, } \\
\text { IFA; FAOSTAT }\end{array}$ \\
\hline & Biological N fixation & [46] \\
\hline & $\begin{array}{l}\text { Atmospheric deposition to } \\
\text { agricultural areas }\end{array}$ & $\begin{array}{c}\text { European Monitoring and Evaluation } \\
\text { Programme (EMEP) }\end{array}$ \\
\hline & Import-export & Country matrix, [31] based on FAOSTAT \\
\hline & Stock change & FAOSTAT food balance \\
\hline $\begin{array}{l}\text { Agricultural systems NUE (see EU } \\
\text { Nitrogen Expert Panel (2016) }\end{array}$ & & N-budget on the country scale \\
\hline Food processing & & FAOSTAT Food balance \\
\hline $\begin{array}{l}\text { Food } \mathrm{N} \text { food availability for } \\
\text { consumption }\end{array}$ & & $\begin{array}{l}\text { FAOSTAT, note this is the food availability } \\
\text { for consumption }\end{array}$ \\
\hline $\mathrm{N}$ content of food products & & [31] \\
\hline
\end{tabular}

\section{Application of the Country Approach}

The previous section provided the general definition and methodology for estimating $\mathrm{NUE}_{\mathrm{FC}}$. In this section, the applicability of the methodology is tested using detailed national data for the Netherlands. This detailed result can then be compared to the simpler calculation with internationally available data sets in the following section. The $\mathrm{N}$ flows in the food chain of the Netherlands for 2005 are shown in Figure 2. The estimation of the NUE of the food chain $\left(\mathrm{NUE}_{\mathrm{FC}}\right)$ is complicated because of the large trade in food and feed with other countries, which is all included in the FAO database.

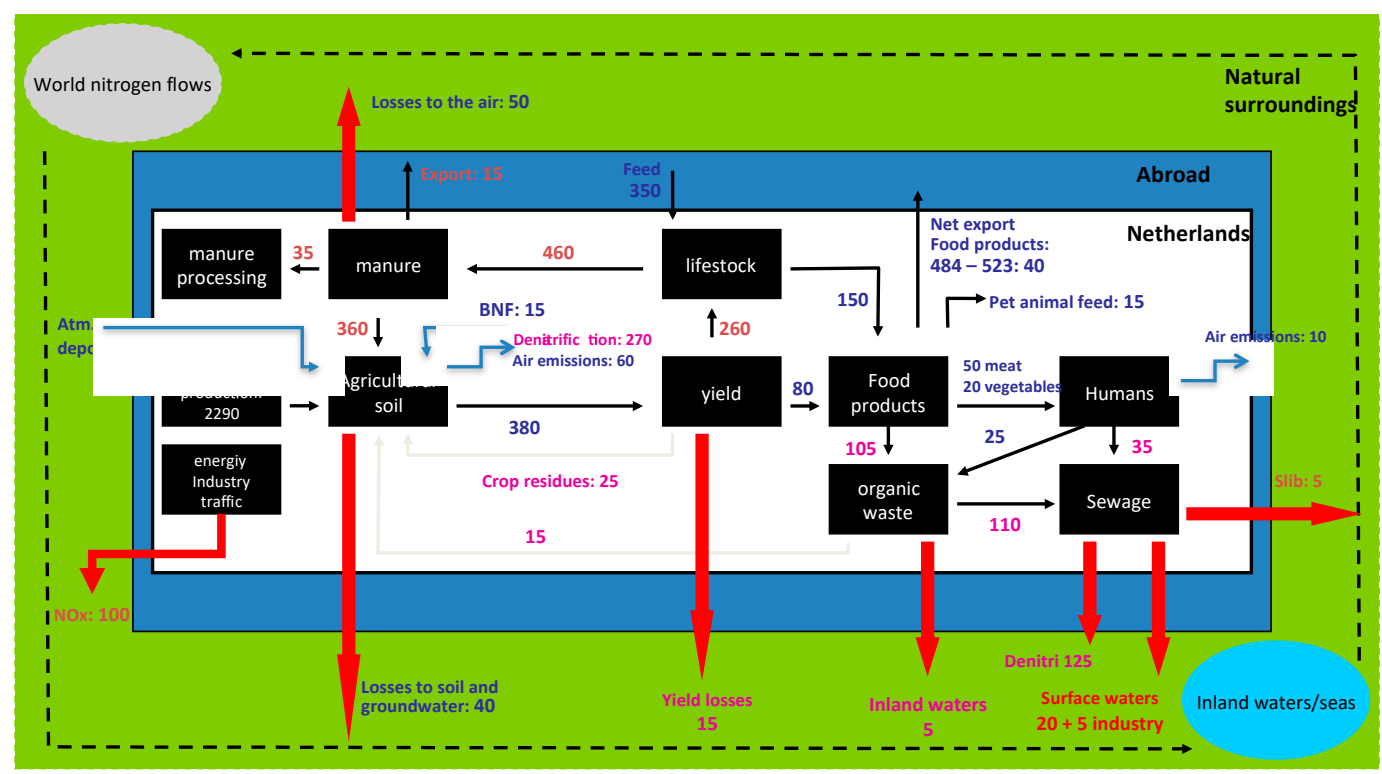

Figure 2. Nitrogen flows in the Netherlands for 2005 (Kton N) estimated using the budgeting (mass balance) method translated from [48].

Using the budget approach, the NUE $\mathrm{FC}_{\mathrm{C}}$ in the Netherlands for 2005 was estimated at $18 \%$ [48]. The total food availability for consumption was 70 Kton N (50 Kton animal protein and 20 Kton vegetal protein). The net import was estimated at $40 \mathrm{Kton}$ (523 Kton of import of mainly feed for animals and $484 \mathrm{Kton}$ of exported food products). The total input of new $\mathrm{N}$ to the system includes fertilizer ( $280 \mathrm{Kton})$, imported feed (350 Kton), BNF (15 Kton) and atmospheric deposition to 
agricultural soils (55 Kton) [48]. Most of the atmospheric deposition results from the national sources (ammonia emissions from agriculture and NOx emissions from fossil fuels). The NUE $\mathrm{FC}_{\text {can }}$ be split into a food processing and a food production component. Food processing was calculated using Equation (1) and the data from Figure 2; the efficiency of the food processing sector was $48 \%$ (including recycling of $15 \mathrm{Kton}$ ), which means that $48 \%$ of $\mathrm{N}$ is retained during processing. The production of food products (up to the food processing: the farm gate efficiency) has an efficiency of $36 \%$.

The $\mathrm{NUE}_{\mathrm{FC}}$ for the consumption of plant and animal protein can only be calculated separately if the input as New $\mathrm{N}$ for the two sectors (crop production and livestock production) is known. Here, corrected fertilizer and manure inputs were used. This was achieved using the ratio of the output ( $80 \mathrm{Kton}$ ) over the input to livestock ( $260 \mathrm{Kton})$ to correct for the animal and plant protein inputs. The resulting $\mathrm{NUE}_{\mathrm{FC}}$ for plant protein in the Netherlands is $12 \%$ and for animal protein $6 \%$ (without the net export of protein).

The Netherlands has a high export/import ratio because of the large trade in feed and food. These large flows greatly affect the accuracy of $\mathrm{NUE}_{\mathrm{FC}}$. Therefore, the net import (import-export) instead of the ratio of export over import is used in Equation (1).

\section{NUE in the Netherlands Based on FAOSTAT Data Compared to National Statistics}

For the application of Equation (1), consistent data have to be used, such as the FAOSTAT Food Balances (see Table 2). The level of detail used in the calculations depends on the availability of data. For each food category of the FAOSTAT food balance the nitrogen content was derived from [31] to calculate the nitrogen entering the household (N Consumed). FAOSTAT data were used on country $\mathrm{N}$ input (fertilizer, BNF, feed, import-export and stock) and protein food availability for consumption data to calculate the country average $\mathrm{NUE}_{\mathrm{FC}}$ using Equation (1).

Table 3 shows the comparison between the Netherlands $\mathrm{NUE}_{\mathrm{FC}}$ as derived from the detailed national statistics using Equation (1) ([48]) and when data from broader and more general databases available for all countries are used. The FAOSTAT data are different from the data for the Netherlands as derived from national statistics. The reason is mainly because different food components are included with different $\mathrm{N}$ contents. The NUE $\mathrm{FC}_{\text {b }}$ based on the FAOSTAT data is $18 \%$ higher than that based on national statistics. In recent years, manure export has increased from about $10 \mathrm{Kton} / \mathrm{yr}$ in the 1990 s to currently $40 \mathrm{Kton} / \mathrm{yr}$, which makes it an important component to take into account. However, these data are not available in FAOSTAT.

Table 3. Comparison of different components of the nitrogen balance in the Netherlands (2008) and resulting $\mathrm{NUE}_{\mathrm{FC}}$ as calculated using Equation (1) in this report.

\begin{tabular}{cccc}
\hline & & This Study & Roell and Erisman [48] \\
\hline & Kton N/yr & Kton N/yr \\
\hline yutput & Consumption & 112 & 2005 \\
\hline & Export food/feed & 292 & 70 \\
\hline & Manure export (national data) & 15 & 484 \\
\hline Input & Fertilizer & 279 & 77 \\
\hline & BNF & 4 & 280 \\
\hline Deposition & 49 & 15 \\
\hline Net annual change & Annual changes in stock & 392 & 56 \\
\hline & & 18 & $\%$ \\
\hline & NUE & 25 & 18 \\
\hline & NUE (incl. manure export) & 26 & 22 \\
\hline
\end{tabular}

Table 3 shows that the NUE $\mathrm{FC}_{\mathrm{C}}$ using the different datasets come to somewhat different outcomes (respectively $25 \%$ and $18 \%$ ). When manure export is taken into account the results are within $20 \%$ of 
each other. The major differences are caused by the differences in imports and exports and in food availability data. The latter depends strongly on the components that are taken into account.

\section{Country Level NUEFC in the EU Based on FAOSTAT}

National data were used for a set of European countries to calculate $\mathrm{NUE}_{\mathrm{FC}}$ using Equation (1) and the data as indicated in Table 2. The resulting $\mathrm{NUE}_{\mathrm{FC}}$ for the countries are plotted in Figure 3 for the year 2008. It shows that there are large differences between countries: Ireland had the lowest NUE $(10 \%)$, while Italy had the highest NUE $(40 \%)$ in 2008. The difference in NUE for the countries can be explained by the difference in $\mathrm{N}$ input (such as BNF) and by the import-export ratios. In the next sections, first the NUE values will be compared to the literature values, followed by an estimate of the trends in $\mathrm{NUE}_{\mathrm{FC}}$.

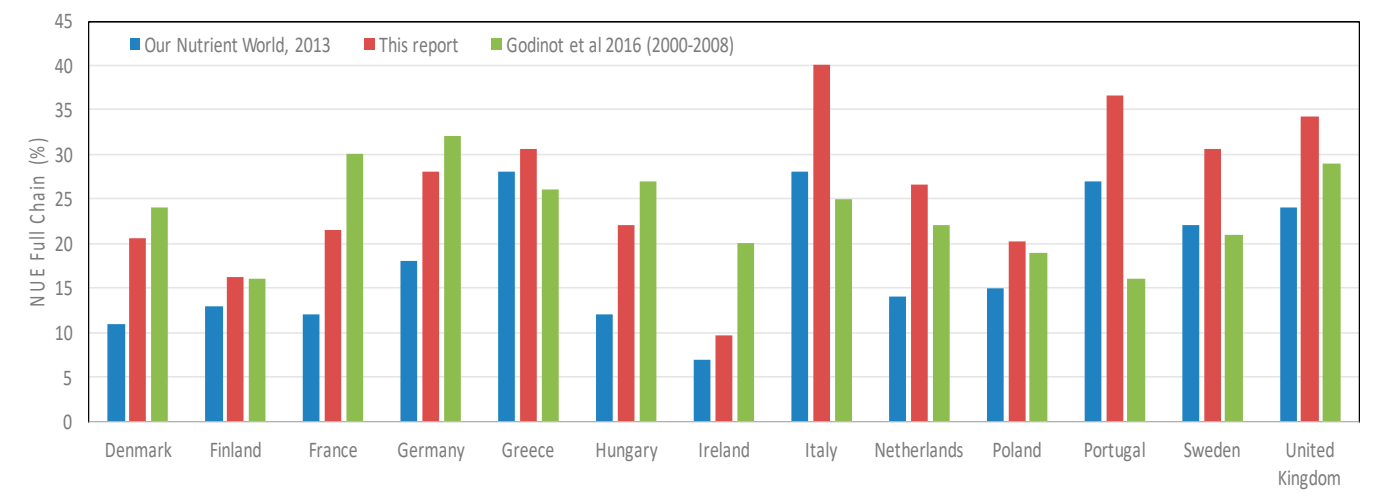

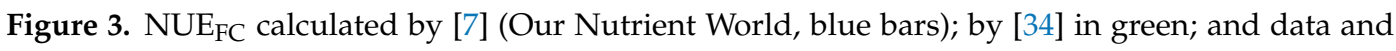
methods proposed in this report for a country-level NUE indicator for 2008 in red.

Earlier FAOSTAT data were used by Sutton et al [7] on country $\mathrm{N}$ input and protein food availability to calculate country average $\mathrm{NUE}_{\mathrm{FC}}$, where the total amount of $\mathrm{N}$ in plant and animal food is considered as a fraction of the total new $\mathrm{N}$ input from mineral fertilizers, BNF and imported feed and food. Figure 3 for the year 2008 shows a comparison of the data in Sutton et al. (2013), and those calculated here for some countries in Europe for the year 2008. Overall, the data by Sutton et al. are at least $25 \%$ lower than calculated here, mainly because of the net import considered here in order to correct for the share of inputs that is used for exported food and feed. Recently, Godinot et al. [34] used several methods to calculate NUE for agricultural production (not the food chain NUE). Their estimates, averaged for the years 2000-2008, are also plotted in Figure 3 for comparison. By definition the NUE for agriculture by Godinot et al., should be higher than the NUE $\mathrm{FC}_{\mathrm{F}}$ since more losses further in the food chain after the farm gate reduce the overall NUE. Figure 3 shows that for half of the countries this is indeed the case, but for Italy, the Netherlands, Portugal, Sweden and the UK, the NUEFC values are higher than those for agriculture. The differences clearly represent the uncertainty in the data and approaches. If the differences between the three methods are considered as a measure of the uncertainty, the $\mathrm{NUE}_{\mathrm{FC}}$ calculated here has an uncertainty of at least $25 \%$ (calculated as the average standard deviation between the different national values).

\section{Country Level $\mathrm{NUE}_{\mathrm{FC}}$ in the EU between 1980 and 2011}

Figure 4 shows the trend for different countries in Europe between 1980 and 2011. Again, Italy shows the highest and Ireland the lowest $\mathrm{NUE}_{\mathrm{FC}}$. Overall, $\mathrm{NUE}_{\mathrm{FC}}$ increased for all countries with time mainly due to the reduction in fertilizer use and a steady increase in the availability of protein for consumption, either produced nationally or through import. The changes over the years are not smooth because of the different changes in N-stock and import and export of $\mathrm{N}$. In some years the stock increased and only reduced in the following year. Therefore, when trends are presented in 
$\mathrm{NUE}_{\mathrm{FC}}$ it is better to use moving averages of three years. Some countries showed an initial increase until 1990 and a subsequent decrease. This is especially true for the Eastern European countries and has to do with the economic situation that drastically changed since 1989 after the breakdown of the wall and with the reduction in fertilizer subsidies, which influences the input as well as the output.

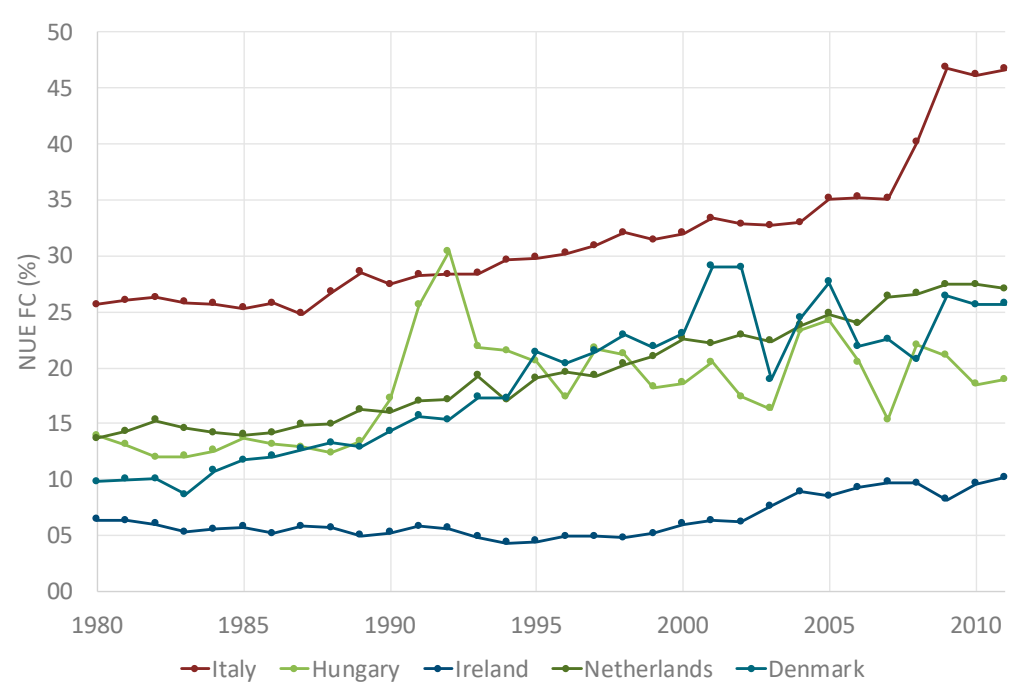

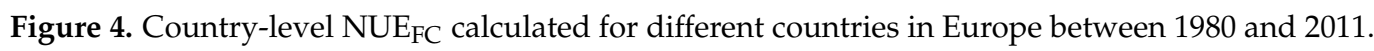

\section{Factors Determining $\mathrm{NUE}_{\mathrm{FC}}$}

There are several factors that influence the $\mathrm{NUE}_{\mathrm{FC}}$. In this section we discuss total $\mathrm{N}$ input, import-export and BNF. Five European countries were selected, which show different levels and trends, to determine the influences of the different factors: Hungary, Ireland, Italy, The Netherlands and Denmark. Figure 5 shows the relationship between $\mathrm{NUE}_{\mathrm{FC}}$ and the total input of new $\mathrm{N}$ (nominator of Equation (1)) on a per capita basis. Overall the trend is the same: if the total $\mathrm{N}$ input increases, $\mathrm{NUE}_{\mathrm{FC}}$ decreases. $\mathrm{NUE}_{\mathrm{FC}}$ strongly depends on the per capita $\mathrm{N}$ input, mainly because the total consumption increases with the population number. The curve in this graph is not unexpected, but the position and trends of the individual countries are interesting. These might be caused by the types of food produced in that country, but we do not have the information to test this. The aim should be to move up the curve towards higher $\mathrm{NUE}_{\mathrm{FC}}$ with lower per capita $\mathrm{NUE}_{\mathrm{FC}}$.

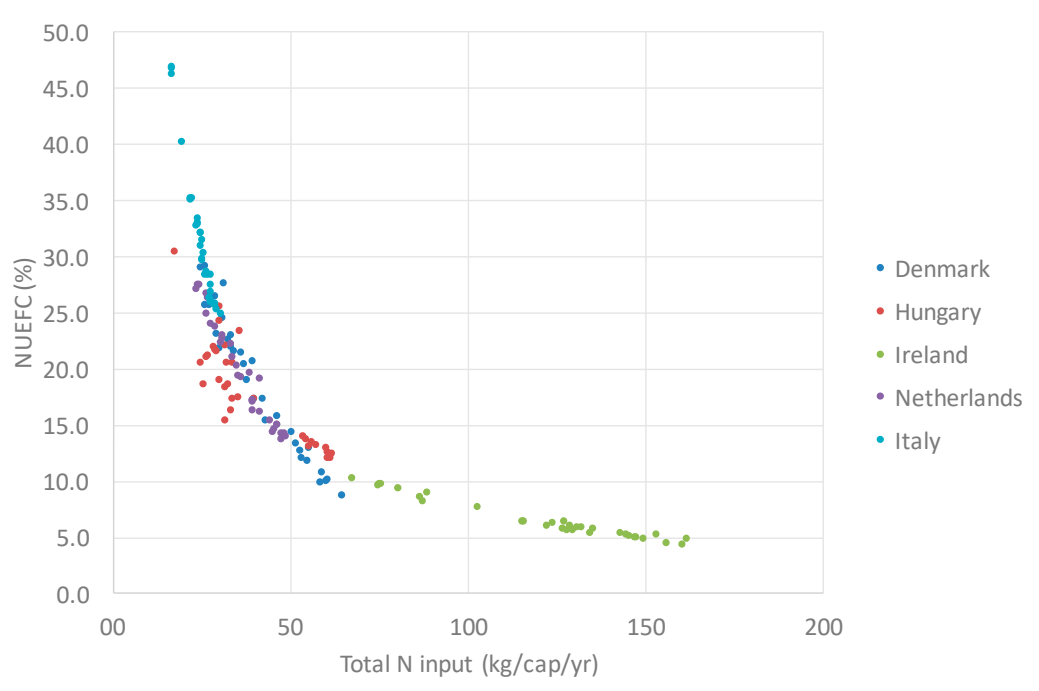

Figure 5. Relationship between $\mathrm{NUE}_{\mathrm{FC}}$ and the total per capita $\mathrm{N}$ input. 
Another important factor is BNF. In the calculation, BNF is taken as new $\mathrm{N}$ and thus if BNF increases, NUE decreases. However, countries that have a high NUE, such as Italy, have a higher BNF input. This might be explained by the type of agricultural system in the different counties. If BNF is high, the use of soil nitrogen for crop production is higher and less fertilizer is used, therewith the NUE of the agricultural system compared to systems using inorganic nitrogen inputs is lower. Therefore higher $\mathrm{NUE}_{\mathrm{FC}}$ is observed. This, however, needs to be further quantified.

As shown for the Netherlands, the import-export ratio is very important in the calculation of NUE. The net import was taken into account to calculate $\mathrm{NUE}_{\mathrm{FC}}$ instead of the ratio of export over import as explained earlier. For the Netherlands, the imported N, mainly as feed, is processed and exported as food leaving behind the wasted N. Italy depends on import for their food supply. For both countries it is shown that if the net import goes up NUE increases. There is no such relation for the net-exporting countries. It must be emphasised here that the NUE for the imported $\mathrm{N}$ has not been taken into account and thus is implicitly assumed to be $100 \%$, just like the NUE for exported products, which is untrue. In the next stage of development of the $\mathrm{NUE}_{\mathrm{FC}}$, either NUE of imported products should be included with a value that is based on the production and processing in the exporting country. Alternatively, one would have to follow in detail the process level of products being imported and exported, and attribute what happens in each (foreign) country individually-this is obviously a task not easily feasible, and needs to be tackled in a more elaborative approach (i.e., in the future).

\section{Use of the Indicator}

This section discusses if and how the indicator can be used to support policy and what is needed to further develop the indicator. A target for policy could be the use of the NUE indicator in relationship to per capita consumption. The World Health Organization recommends levels of protein consumption for age classes split between men and women. The average recommended level of consumption (expressed in terms of N) is $3 \mathrm{~kg} \mathrm{~N} /$ capita/year [49]. In general, it would be expected that the NUE will increase if the consumption per capita decreases, because the expectation is that this goes along with lower inputs. This holds especially for a decrease in processed food and a change towards more plant protein. For policy, it could be the aim to increase NUE, together with maintaining nutrition levels, but not exceeding recommended levels of protein consumption. For all countries the food availability for consumption is far above the recommended level. For most countries, the food availability goes up with higher NUE, except for Ireland, which shows no trend, and Hungary, which shows a decrease in food availability relative to NUE. There is therefore no clear relationship between food availability for consumption and NUE. This questions the usability of the indicator based on the current calculations. In the future this needs to be further tested.

Given the limited availability of data and the uncertainty associated with the different steps in the food system, it appears that the $\mathrm{NUE}_{\mathrm{FC}}$ indicator cannot be used easily for the optimization of the food production-consumption chain, nor can it be used for food labelling. The $\mathrm{NUE}_{\mathrm{FC}}$ indicator proposed here is suitable for supporting national policies and provides information about nitrogen consumption relative to the new $\mathrm{N}$ used to produce the consumed N. For food labelling, Leach et al. [20] propose to use the footprint approach.

The applicability of the $\mathrm{NUE}_{\mathrm{FC}}$ depends strongly on the availability of data, such as crop-specific fertilizer and manure data, data on the recycling of manure, BNF and deposition, soil N availability and use, $\mathrm{N}$ food availability for consumption, and loss fractions for each step in the food system. It was illustrated here for the Netherlands that when these data are available, the NUE $\mathrm{FC}_{\mathrm{FC}}$ can be calculated (excluding energy and transportation). It was shown that for the Netherlands the availability of protein $\mathrm{N}$ for consumption increased over the past decades both due to increased production nationally and through imports, while the $\mathrm{N}$ inputs decreased, implying an improved NUE $\mathrm{FC}_{\mathrm{FC}}$. The current $\mathrm{NUE}_{\mathrm{FC}}$ is still in the low range, $12 \%$ for vegetal products and $6 \%$ for animal protein, and there is room 
for improvement of the methodology of estimating $\mathrm{NUE}_{\mathrm{FC}}$, especially by addressing the balance of feed import.

The $\mathrm{NUE}_{\mathrm{FC}}$ indicator has the potential to provide information about the developments of the national $\mathrm{NUE}_{\mathrm{FC}}$. For policy applications, one can imagine to set a so-called protein target, defined for example as the NUE for the whole food chain, or a food processing target. One could also think of targeting the share of plant protein in the whole food chain to increase NUE. However, the robustness of the indicator has to be improved by better including the NUE of imported protein and by separating national production from the import/export of protein. The ratio and the differences between animal protein and plant protein could also provide important information about the national $\mathrm{NUE}_{\mathrm{FC}}$.

\section{Next Steps}

This initial study points in promising directions but, at the same time, raises numerous issues regarding data availability and the way that various values are used in calculations. The treatment of import and export of food is a particularly tricky aspect that has not yet been satisfactorily resolved. Estimations of biological nitrogen fixation also need better quantification. The way manure is treated in the calculations may also need further consideration. Deriving values for $\mathrm{NUE}_{\mathrm{FC}}$ at the national level is therefore challenging and differences between countries in the examples given should be interpreted with great care until the methods and data are further improved.

The framework presented in this paper does not take into account the role of the circular economy in $\mathrm{N}$ management. With the complexity of the food system, a circular economy is important in moving towards sustainability because it promotes the recycling of food wastes either as compost or feed to animals, recycling of sewage in agricultural soils, and reuse of crop residues either as compost or animal feed, etc. These recycled flows are not taken into account in this framework. If this indicator is to be used for policy and decision-making, the focus should be on how to stimulate the circularity in nitrogen management.

The logical next step is to further develop, improve and test a comprehensive $\mathrm{NUE}_{\mathrm{FC}}$ indicator as proposed now in Equation (1). This requires further data collection for Europe. This approach requires estimations of country-specific $\mathrm{N}$ flows for different steps in the food system, including the NUE for imported protein and the distinction between exported protein and national consumption. These $\mathrm{N}$ flows may be used to calculate the $\mathrm{NUE}_{\mathrm{FC}}$ for the new $\mathrm{N}$ inputs and include the recycling of crop residues and manure. This can be carried out for each country in Europe. An uncertainty analysis should be carried out on the national scale per crop and/or meat product. Also, the uncertainty of the data and the robustness of the inventory systems need to be assessed. Finally, the next steps needed to develop the indicators for relevant policy will include a test of the consistency and quality of the data and the set-up of a baseline calculation and a monitoring program.

Acknowledgments: The authors gratefully acknowledge financial support from Fertilizers Europe. We acknowledge the comments and suggestions of the members of the EU Nitrogen Expert Panel on draft versions. We are very grateful for the input from Oene Oenema and David Powlson and their helpful comments on the methodology development.

Author Contributions: The manuscript was written by J.W.E., A.L., A.B., L.C. and J.G. did the literature study on indicators. All authors contributed to the development of the indicator and reviewed the paper. A.B. and J.W.E. are responsible for the calculations and results.

Conflicts of Interest: The authors declare no conflict of interest.

\section{Appendix A}

This literature review accounts for the major approaches used to assess nitrogen efficiency over the food system: (1) life cycle analysis (LCA); (2) nitrogen footprint; (3) nitrogen budget; and (4) environmental impact assessment. We reviewed the merits and drawbacks to of each approach. 
Appendix A.1 Life Cycle Analysis (LCA)

Life cycle analysis quantifies the potential environmental impacts of a product, process, or service by assessing the inputs and outputs within a defined system boundary. The approach is conducted by first compiling an inventory of material inputs and environmental releases. The inputs and losses are then linked to environmental impacts, such as eutrophication potential or acidification potential. All losses and impacts are reported relative to a defined functional unit, such as $1 \mathrm{~kg}$ of beef or another product. Software tools are available for LCA.

A benefit of LCA is that it can be widely applied through available LCA software. Though LCAs can be applied to a range of 'products' and locations, their design also has limitations. When conducting a LCA, choosing an appropriate system boundary and functional unit is key to expressing results in a succinct yet widely applicable manner. Comparing LCA results is only appropriate when two systems have the same system bounds and functional units. Harris and Narayanaswamy [15] suggest choosing a functional unit that reflects the way a commodity is traded so that results may be translated across trans-national boundaries, and expanded to include economic analyses. Most studies examined here reflected this notion when choosing their functional units. Brentrup et al. [11] performed calculations in terms of tons of wheat, while [14] focused on $1 \mathrm{MJ}$ of biofuel production. When using a software tool, the factors built in to the LCA tools are often not applicable to a system of interest and must be modified.

Though LCAs can link to environmental impacts, they are also data and resource intensive, which can be a significant disadvantage to regional-level analyses. Often data inputs are directly measured, which, though advantageous to site-specific investigations, are difficult to scale to a region.

Life cycle analysis studies:

- $\quad$ Ahlgren et al. [9]: Sweden (straw).

- Brentrup et al. [10]. Germany (sugar beets).

- Brentrup et al. [11]. Europe (no crop specified—general background/challenges associated with farm level LCA).

- Brentrup et al. [11]. United Kingdom (winter wheat).

- Caffrey et al. [12]: United States (LCA challenges/perspectives).

- Cederberg et al. [13]: Sweden (milk).

- Gallejones et al. [14]: Spain (biofuel).

- Grizzetti et al. [38]: LCA of food waste across the food system.

- Harris and Narayanaswamy. [15]: Australia (reviews cases).

- Liao et al. [16]: Model of nitrogen releases in LCA of crop production.

- Pelletier \& Leip [17]: Nitrogen characterization factors that can be used to aggregate nitrogen flows in LCA. Tested using average EU-27 consumption.

- Thomassen et al. [18]. The Netherlands (conventional/organic milk).

\section{Appendix A.2 Nitrogen Footprint}

The footprint methodology captures total nitrogen losses to the environment resulting from the production of a defined unit of food. Usually completed on a regional scale, $\mathrm{N}$ footprints have the capacity to span the entire chain of a product from farm level and food processing to transport and consumption. Though often employing mass balance techniques that are commonly used in nitrogen budget approaches, $\mathrm{N}$ footprints aim to quantify commodities in a manner that allows inter-product comparisons to be made and conclusions to be drawn.

Though $\mathrm{N}$ footprints do not allow users to link products to environmental or social impacts, they do provide an advantage in that their outcomes are on the same platform, and can thus be compared. These comparisons are, in part, due to the ability of an $\mathrm{N}$ footprint to function on a regional level or above. Generalized processing and food waste data can often be used in place of site-specific measurements as are usually required in a LCA. 
$\mathrm{N}$ footprint approaches are also able to model internal $\mathrm{N}$ fluxes and credit the system where recycled N should be accounted for, as in [20]. Chatzimpiros and Barles [19] were able to account for BNF and atmospheric deposition in their $\mathrm{N}$ footprint calculations, while also crediting manure excretions back into the system for crop production.

Nitrogen footprint studies:

- Chatzimpiros and Barles. [19]: France (beef, pork, and milk).

- Leach et al. [20]: the Netherlands and the United States (broccoli, lettuce, tomato, spinach, potatoes, beans, corn, broiler chicken, pork, beef, fish, milk).

- $\quad$ Leip et al. [32]: European Union (vegetable and animal products).

- Oita et al. [50]: Global (The nitrogen footprint of nations).

- Pierer et al. [22]: Austria (poultry, pork, beef, milk, vegetables and fruit, potatoes, legumes, cereals).

- Stevens et al. [21]: United Kingdom (poultry meat, pigmeat, beef, milk, fish and seafood, cereals, pulses, starchy roots, vegetables).

\section{Appendix A.3 Nitrogen Budget}

Nitrogen budget approaches compile the inputs and outputs of nitrogen across the boundaries of a system in order to model and quantify internal nitrogen fluxes by using a mass balance approach. Within this approach, we classified two subcategories, the nitrogen balance indicator approach and the food system waste/loss approach. A nitrogen indicator uses the mass balance methodology to measure the difference between the $\mathrm{N}$ available to an agricultural system and the uptake of nitrogen by agriculture. The food system waste/loss category is similar, but emphasizes the losses of $\mathrm{N}$ through waste, especially during transport and processing, where losses can be high.

A major advantage to this approach is its ability to quantify indicators, which are often used to supply information on other variables that cannot be measured directly. In the case of a FAO study in 2011, Gustavsson et al. [40] used mass flows models to account for the loss or waste incurred during each step of the production process. This included agricultural production, postharvest production, handling and storage, processing, distribution, and consumption, indicating its widely applicable nature throughout each stage of the chain. However, though $\mathrm{N}$ budgets can effectively quantify intermediary steps, they often have difficulty determining the fates of the system outputs, and examining internal flows in a greater level of a detail.

Nitrogen budget studies:

- Bleken and Bakken [26]: Nitrogen efficiency of food production in Norway.

- Dalgaard et al. [27]: Poland, the Netherlands, France, Italy, Scotland, and Denmark (poultry, sheep, beef and dairy cattle, pigs, maize, forage, oilseed rape, "horticultural crops", silage maize, winter wheat, "leguminous plants", water buffalo—dairy, alfalfa, "vegetables", grass/clover, peas, oats, fava bean, rye, barley, triticale, and wheat) Cover inputs/exports: beet pulp, cereals, eggs, feed milk, fresh milk, alfalfa, grass, grass/clover, hay, various concentrates, meat, rape cake, soybeans, soybean oil cake, straw, sugar beets, whey, and silage—alfalfa, beet pulp, clover grass, grass, maize, whole crop.

- Galloway and Cowling [28]: Global nitrogen efficiency of plant and animal production.

- Grizzetti et al. [38]: quantifies the nitrogen loss to the environment related to food waste at consumption at the global and European scale and analyses its relative impact on the environment. Examined: cereals, roots and tubers, oilseed and pulses, fruit and vegetables, meat, fish and seafood, and milk (Global).

- Gustavsson et al. [39]: Uses mass flows model to account for losses and waste incurred during each step of the commodity's food supply chain. Examined: cereals, roots and tubers, oilseeds and pulses, fruits, vegetables, meat, fish and seafood and dairy products. A variety of 
countries were considered, referred to in paper as industrialized (medium/high income) countries and developing (low income) countries.

- Howarth et al. [29]: USA nitrogen budget, including food and energy production and consumption.

- Isermann and Isermann [44]: Germany nitrogen balance for food and feed production and consumption.

- Lassaletta et al. [31]: Analyzes importance of international trade of food and feed in the alteration of the $\mathrm{N}$ cycle at the global scale. Considered 12 regions, with 210 countries (incl. Africa, Europe, India, N. America, etc.) Examined 407 vegetable and 128 animal products.

- Leip et al. [32]: Regionalized focus for Europe (cereals, oilseeds, pulses, fodder maize, fodder beet, grass, beef, pork, poultry meat, cow milk, eggs).

- Ma et al. [33]: NUFER model (Nutrient flows in Food chains, Environment and Resources use) is an integrated assessment model for analysing $\mathrm{N}$ and $\mathrm{P}$ flows in the food chain from both production and consumption.

- Godinot et al. [34]: Proposes new farm nitrogen budget indicators.

- Oenema et al. [1,35]: The Netherlands (dairy cattle). The UK and the Netherlands-global perspective on manure management (pig, poultry, beef \& dairy cattle).

- Oita et al. [50]: Multi-Regional Input-Output analysis that assesses trade-related impacts from a consumption perspective. Applied at a global scale to quantify nations' footprints. Examined 15,000 industry sectors and 189 countries.

- Parfitt et al. [40]: Review of global food waste literature throughout the supply chain.

- Shindo et al. [36]: Reports the nitrogen load for East Asian countries.

- Westhoek et al. [45]: Assesses environmental impacts and health effects of diets with reduced meat and dairy in Europe.

\section{Appendix A.4 Environmental Impact Assessment}

Environmental impact assessments provide a means of evaluating the likely environmental impacts of a proposed product, while also taking into account inter-related socio-economic, cultural, and human health impacts both beneficial and adverse.

Though results are can be attributed to specific impacts, the analysis stops short here. Impacts are unable to be objectively compared, as a definitive ranking system has yet to be developed that will allow scientists to compare a product's carcinogenic effects to the degree of eutrophication it causes. Similarly to a LCA, it can be data intensive and site specific, negating the ability to generalize these impacts to another similar product. For this reason, environmental impact assessments cannot be widely applied without significant time and resource inputs.

Environmental impact assessment studies:

- OECD [41]: The guide is not intended to target one specific country, but the following are member countries of the Organization for Economic Co-operation and Development: Australia, Austria, Belgium, Canada, the Czech Republic, Denmark, Finland, France, Germany, Greece, Hungary, Iceland, Ireland, Italy, Japan, Korea, Luxembourg, Mexico, the Netherlands, New Zealand, Norway, Poland, Portugal, Slovak Republic, Spain, Sweden, Switzerland, Turkey, the United Kingdom and the United States. No specific food types are targeted in this analysis.

- Payraudeau and van der Werf [42] has been applied to the following countries and products/foods:

- Environmental risk mapping: Ecuador (soil nutrient balance), Italy (impacts on water quality).

- LCA: Europe (energy crops), Germany (complete conversion from conventional to organic farming). 
- Environmental impact assessment: Brazil (ag. technology).

- Multi-agent system: France (groundwater evaluation). Thailand (catchment irrigation).

- Linear programming: Germany (farm level—crops not specified), Mali (crops unspecified).

- Agro-environmental indicators: Europe, Bangladesh.

- Van der Werf and Petit [51]: The guide reviews 12 indicator-based methods spanning a variety of countries and agricultural topics. The relevant studies are as follows: Malaysia (cabbage), four undisclosed locations in Europe (energy crops), Philippines (rice), France (integrative farming animal/crop diversity), and Switzerland (farm pollution sources).

\section{Relevant Gaps}

Inconsistent allocation methods are the most notable gaps in each of the reviewed approaches. It is during this phase of the calculations that the most bias is introduced. ISO 14040 standards recommend system expansion and substitution whenever possible, but often these are not viable options due to resource and data limitations. Harris and Narayanaswamy (2009) review alternative methods of allocation and the merits associated with each, including mass weight and economic value. The overwhelming conclusion states that choice of allocation method is subjective, and there has yet to be data supporting one alternative method over the other.

The following gaps were identified in the reviewed methods:

- There is inconsistency in accounting for exports as a portion of national production.

- When performing an N-footprint, some studies chose to include atmospheric emissions and others did not. This can drastically change a food product's environmental footprint.

- If including atmospheric emissions, estimating emissions can often be difficult since emission factors $(\mathrm{EF})$ can vary drastically depending on a variety of variables (i.e., soil type, amount of precipitation, amount of $\mathrm{N}$ fertilizer applied, etc.)

- Additionally, emission factors must be included from the extraction of raw materials to make fertilizer, from all farm equipment on a farm site, as well as emissions from manure.

- Variability in accounting for biological $\mathrm{N}$ fixation.

- Not many studies differentiate between new (e.g., synthetic fertilizer) vs. recycled (e.g., manure) N inputs.

- Difficulty with and a relatively high amount of inconsistency in approaching crop rotations, which, most articles agree, is a limitation in calculating an accurate $\mathrm{N}$ footprint.

- Animal product allocation at farm gate. There are a variety of methods for determining how much of the N-footprint should be allocated toward multiple products resulting from one animal (for example: butter, milk, meat, etc.), and it is difficult to choose the appropriate methodology.

- Weight, economic value, system expansion, by-product displacement, etc.

- Accurately assessing nitrogen leaching. This usually needs to use a model, and in order to estimate leaching, most studies suggested examining farm dynamics on a relatively small scale.

- Main limitation: Connecting the results of the N-footprint, LCA, etc. to actual environmental impacts. This is the number one limitation in all of the studies.

\section{Appendix B}

Detailed literature review of four full-chain nitrogen efficiency indicators: Life cycle analysis (Table A1), nitrogen footprint (Table A2), nitrogen budget (Table A3), and environmental impact assessment (Table A4). 
Table A1. Literature review: Life cycle analysis as a nitrogen efficiency indicator.

\begin{tabular}{|c|c|c|c|c|c|c|}
\hline Reference & $\begin{array}{c}\text { Study } \\
\text { Domain }\end{array}$ & Methodological Scope & Key Features & NUE Value & $\mathrm{N}$ Input Values & $\mathrm{N}$ Output Values \\
\hline $\begin{array}{l}\text { Ahlgren et al., } \\
2012\end{array}$ & $\begin{array}{l}\text { National } \\
\text { (Sweden) }\end{array}$ & $\begin{array}{l}\text { Land use, energy use and greenhouse } \\
\text { gas emissions from the production of } \\
\text { ammonium nitrate based on biomass. } \\
\text { Cradle-to-gate. }\end{array}$ & $\begin{array}{l}\text { 1. Describes how } \mathrm{N} \text { flows change in response to a } \\
\text { possible decision and includes effects both inside } \\
\text { and outside the life cycle of the system. 2. Identify } \\
\text { short and long-term marginal target changes to } \\
\text { determine fluctuations in system. } \text {. Accounts for } \\
\text { recycling of nitrogen fertilizers. }\end{array}$ & $n / a$ & $\mathrm{n} / \mathrm{a}$ & $\mathrm{n} / \mathrm{a}$ \\
\hline $\begin{array}{l}\text { Brentrup et al., } \\
2001\end{array}$ & $\begin{array}{l}\text { National } \\
\text { (Germany) }\end{array}$ & $\begin{array}{l}\text { Determine Eco-indicator values \& } \\
\text { evaluate the impact of three different } \\
\text { nitrogen fertilizers on the entire } \\
\text { environmental burden associated with } \\
\text { a sugar beet production system. }\end{array}$ & $\begin{array}{l}\text { 1. Life Cycle Impact Assessment-aggregate } \\
\text { inventory data to produce one inder representing } \\
\text { environmental burden. Particularly weighting } \\
\text { factors using the "distance-to-target principle": } \\
\text { ratio b b current level and a target level of } \\
\text { an effect. 2. Key issues missing in the Eco-indicator } \\
\text { 95 method: the use of resources and land. } \\
\text { 3. Comparative analysis related to global warming, } \\
\text { acidification, eutrophication and summer smog. } \\
\text { 4. Impact assessment cannot be performed } \\
\text { site-specific. }\end{array}$ & $\mathrm{n} / \mathrm{a}$ & $\begin{array}{l}\mathrm{N} \text { minimum in soil in spring, } \\
\text { fertilizer } \mathrm{N} \text {, atmospheric } \mathrm{N} \\
\text { deposition }(15 \mathrm{~kg} / \mathrm{ha}) \text {, net } \mathrm{N} \\
\text { mineralization during vegetation } \\
\text { (15 kg/ha/day). }\end{array}$ & $\begin{array}{l}\text { Ammonia volatilization }(1-20 \% \\
\text { applied), nitrous oxide emissions, } \\
\mathrm{N} \text { removal with beets (1.8 kg/t } \\
\text { sugar beet), } \mathrm{N} \text { content of leaves } \\
(4 \mathrm{~kg} / \mathrm{tea} \text { eses), } \mathrm{N} \text { uptake of winter } \\
\text { wheat in autumn (5-10\% of total } \mathrm{N} \\
\text { uptake, } 210 \mathrm{~kg} / \mathrm{ha}) .\end{array}$ \\
\hline $\begin{array}{l}\text { Brentrup et al., } \\
2004\end{array}$ & $\begin{array}{l}\text { Regional } \\
\text { (Europe) }\end{array}$ & $\begin{array}{l}\text { Evaluates impact of emissions and } \\
\text { resource consumption associated with } \\
\text { crop production on the following } \\
\text { environmental effects: depletion of } \\
\text { abiotic resources, land use, climate } \\
\text { change, toxicity, acidification, and } \\
\text { eutrophication. }\end{array}$ & $\begin{array}{l}\text { New characterization method for abiotic resources } \\
\text { and land use; particularly new aggregation, } \\
\text { normalization and weighting. Foundation of } \\
\text { weighting factors used the 'distance-to-target } \\
\text { principle'. }\end{array}$ & $\mathrm{n} / \mathrm{a}$ & $\mathrm{n} / \mathrm{a}$ & $\mathrm{n} / \mathrm{a}$ \\
\hline $\begin{array}{l}\text { Brentrup et al., } \\
\quad 2004\end{array}$ & $\begin{array}{l}\text { National } \\
\text { (United } \\
\text { Kingdom) }\end{array}$ & $\begin{array}{l}\text { Environmental impact of different } \mathrm{N} \\
\text { fertilizer rates in winter wheat } \\
\text { production. }\end{array}$ & $\begin{array}{l}\text { Assess resource depletion and environmental } \\
\text { impacts. Impact categories: land use, climate } \\
\text { change, toxicity, acidification, eutrophication. }\end{array}$ & $\mathrm{n} / \mathrm{a}$ & $\begin{array}{l}\text { Extraction of raw materials, } \\
\text { production and transportation of } \\
\text { inputs, all ag operations in field, } \\
\text { application of fertilizer } \\
\text { (0-288 kg N/ha). }\end{array}$ & $\begin{array}{l}\text { Nutrient removal in grain and } \\
\text { straw ( } 30-212 \mathrm{~kg} \mathrm{~N} / \mathrm{ha}) \text {, emissions } \\
\text { due to energy consumption, } \\
\text { volatilization, leaching. }\end{array}$ \\
\hline $\begin{array}{l}\text { Caffrey and Veal } \\
2013\end{array}$ & $\begin{array}{l}\text { Literature } \\
\text { Review }\end{array}$ & $\begin{array}{l}\text { Review inconsistent methodologies } \\
\text { associated with co-products, regional } \\
\text { and crop specific management } \\
\text { techniques, temporal variations, spatial } \\
\text { variations, and nonpoint emission } \\
\text { sources. }\end{array}$ & $\begin{array}{l}\text { 1. Land use change- examines direct and indirect } \\
\text { implications regionally and globally. Discusses } \\
\text { leachate and volatilization models, the } \\
\text { consequences and processes of livestock production } \\
\text { that should be considered. 2. Enteric fermentation } \\
\text { and manure handling. 3. Considerations when } \\
\text { including aquaculture. 4. Recommends the } \\
\text { consideration of economics when comparing } \\
\text { systems to determine the best mitigation strategies. }\end{array}$ & $\mathrm{n} / \mathrm{a}$ & $\mathrm{n} / \mathrm{a}$ & $\mathrm{n} / \mathrm{a}$ \\
\hline $\begin{array}{c}\text { Cederberg et al., } \\
2000\end{array}$ & $\begin{array}{l}\text { National } \\
\text { (Sweden) }\end{array}$ & $\begin{array}{l}\text { LCA comparing organic and } \\
\text { conventional milk production in } \\
\text { Sweden in terms of environmental } \\
\text { impacts and land requirements. }\end{array}$ & $\begin{array}{l}\text { Conventional milk production was found to have a } \\
\text { larger nitrogen surplus than organic per unit area, } \\
\text { but organic has a greater } \mathrm{N} \text { surplus per unit milk. }\end{array}$ & $\mathrm{n} / \mathrm{a}$ & $\mathrm{n} / \mathrm{a}$ & $\mathrm{n} / \mathrm{a}$ \\
\hline
\end{tabular}


Table A1. Cont.

\begin{tabular}{|c|c|c|c|c|c|c|}
\hline $\begin{array}{l}\text { Gallejones et al., } \\
2014\end{array}$ & $\begin{array}{l}\text { National } \\
\text { (Spain) }\end{array}$ & $\begin{array}{l}\text { 1. Evaluates the variability due to } \\
\text { site-specific conditions of climate and } \\
\text { fertilizer management of the LCA of two } \\
\text { different productst biodiesel from rapeseed } \\
\text { and bioethanol from wheat. 2. Improves } \\
\text { the estimates of the LCA impacts due to N } \\
\text { losses normally estimated with unspecific } \\
\text { emission factors, that contribute to the } \\
\text { impact categories analysed in the LCA of } \\
\text { biofuels at local scale. }\end{array}$ & $\begin{array}{l}\text { 1. Integrated model simulations into a LCA assessment of } \\
\text { biofuels; model accounted for local factors in the } \\
\text { estimation of yield and N losses. 2. Crop production was } \\
\text { the most influencing stage to every impact category. } \\
\text { 3. Nitrous oxide subject to large variability in the LCA. } 4 . \\
\text { Coproducts addressed with system expansion. }\end{array}$ & $\mathrm{n} / \mathrm{a}$ & $\begin{array}{l}\text { Soil inorganic N flux (mineralized } \mathrm{N} \\
\text { from SOM, plant debris and organic } \\
\text { amendments to soil), fertilizer } \mathrm{N}, \\
\text { mineralization. }\end{array}$ & $\begin{array}{l}\text { Roots } \mathrm{N} \text {, shoot } \mathrm{N}, \text { grain } \mathrm{N}, \\
\text { volatilization, } \\
\text { denitrification/nitrification/leaching } \\
\text { lossed, handling and storage, } \\
\text { production of biofuel. }\end{array}$ \\
\hline $\begin{array}{l}\text { Harris and } \\
\text { Narayanaswamy } \\
2009\end{array}$ & $\begin{array}{l}\text { Literature } \\
\text { Review }\end{array}$ & $\begin{array}{l}\text { Focuses on LCA agricultural literature } \\
\text { relevant to the pork, poultry, cotton, sugar, } \\
\text { red meat and livestock sectors. }\end{array}$ & $\begin{array}{l}\text { 1. Goals: generally compared the environmental impact of } \\
\text { farming practices or types of fed. . Allocation of } \\
\text { co-products: economic allocation used in the past, but } \\
\text { studies of beef and dairy have shown this to increase } \\
\text { uncertainty. Preference- -system expansion, physical } \\
\text { relationships/causality, composition and economic value. } \\
\text { 3. Merits of foreground (input processes, farm processes } \\
\text { and production processes) and background (mining and } \\
\text { extraction, grain production, transport) data sources. } 4 \text {. } \\
\text { Argues for uncertainty calculations to be incorporated } \\
\text { into LCA results. }\end{array}$ & $\mathrm{n} / \mathrm{a}$ & $\begin{array}{l}\text { Varies by study: fertilizer } \mathrm{N} \text {, soil } \\
\text { organic and inorganic } \mathrm{N}, \\
\text { mineralization, manure, green manure. }\end{array}$ & $\begin{array}{l}\text { Varies by study: root N, grain } \mathrm{N}, \\
\text { residue N, manure, coproducts, } \\
\text { leaching, denitrification, nitrification, } \\
\text { storage, food system processing. }\end{array}$ \\
\hline Liao et al., 2014 & Varies & $\begin{array}{l}\text { Study provides an overview of aspects that } \\
\text { need to be taken into account for improved } \\
\text { modelling of Nr releases in the LCA of crop } \\
\text { production. }\end{array}$ & $\begin{array}{l}\text { 1. On-site crop production must include the harvested } \\
\text { portion of the crop and the soil with a changing depth } \\
\text { down to the water table. } 2 \text {. Nitrate, nitrous oxide and } \\
\text { ammonia should be distinguished within the crop } \\
\text { product system and } b / \mathrm{w} \text { the crop product system and the } \\
\text { ecosphere. 3. Stand-alone LCA studies of crop production } \\
\text { and those coupled with process-based models should be } \\
\text { based on a consistent spatial scale. } 4 \text {. Fate of Nr losses in } \\
\text { the ecosphere should be explicitly modelled in the life } \\
\text { cycle impact assessment phase of the LCA of crop } \\
\text { production. }\end{array}$ & $\mathrm{n} / \mathrm{a}$ & $\begin{array}{l}\text { 1. PRODUCTS \& PROCESSES TO } \\
\text { CONSIDER (multiple inputs \& } \\
\text { outputs). 2. Extraction of natural } \\
\text { resources, fertilisers, pesticides, } \\
\text { machinery, infrastructure, energy, } \\
\text { allocation of crops and crop functions, } \\
\text { crop residues, soil N processes } \\
\text { (volatilization, nitrification, } \\
\text { denitrification, runoff, leaching, } \\
\text { fixation, etc.). }\end{array}$ & \\
\hline $\begin{array}{l}\text { Pelletier \& Leip } \\
2014\end{array}$ & $\begin{array}{l}\text { Regional } \\
\text { (Europe) }\end{array}$ & $\begin{array}{l}\text { Provide set of over } 2000 \mathrm{~N} \text { characterization } \\
\text { factors for use in aggregating } \mathrm{N} \text { flows in } \\
\mathrm{LCA} \text {. Used life cycle data and } \mathrm{N} \\
\text { characterization factors to estimate } \\
\text { aggregated fixed } \mathrm{N} \text { losses for an average } \\
\text { EU-27 consumer. }\end{array}$ & $\begin{array}{l}\text { 1. Provided a set of over } 2000 \text { nitrogen characterization } \\
\text { factors, which can be used to convert } \mathrm{N} \text { species into } \\
\text { weight of total } \mathrm{N} \text { for aggregation. 2. The } \mathrm{N} \\
\text { characterization factors can be used in LCA and other } \\
\text { approaches to estimate total } \mathrm{N} \text {. } 3 \text {. Applying the } \mathrm{N} \\
\text { characterization factors for average EU-27 consumer } \\
\text { using an LCA approach generated findings comparable to } \\
\text { other studies, which confirms the use of the } \mathrm{N} \\
\text { characterization factors. }\end{array}$ & $\mathrm{n} / \mathrm{a}$ & $\begin{array}{l}\text { Inputs for LCA not explicitly described. } \\
\text { Sectors considered in LCA were } \\
\text { nutrition/food, shelter, consumer } \\
\text { goods, and mobility. }\end{array}$ & $\begin{array}{l}\text { Outputs/emissions for LCA not } \\
\text { explicitly described. Sectors considered } \\
\text { in LCA were nutrition/food, shelter, } \\
\text { consumer goods, and mobility. }\end{array}$ \\
\hline $\begin{array}{l}\text { Thomassen et al., } \\
2008\end{array}$ & $\begin{array}{c}\text { National } \\
\text { (Netherlands) }\end{array}$ & $\begin{array}{l}\text { 1. Two Dutch milk production systems } \\
\text { (organic-1 farms, and conventional-10 } \\
\text { farms) were examined from } \\
\text { cradle-to-farm-gate. 2. Animal manure, } \\
\text { animals, milk, roughage/bedding material } \\
\text { were outside of system boundary. } \\
\text { 3. Excluded medicines, seeds, machinery, } \\
\text { buildings, transport or processing of raw } \\
\text { milk. }\end{array}$ & $\begin{array}{l}\text { 1. Integral environmental impact (land use, energy use, } \\
\text { climate change, acidification, and eutrophication and } \\
\text { hotspots were identified. . Conventional: purchased } \\
\text { concentrates were found to be the hotspot in off farm and } \\
\text { total impact for all categories. . . Organici purchased } \\
\text { concentrates and roughage were found to the hotspots in } \\
\text { off farm impact. 4. Allocation of multifinctional processes } \\
\text { was done on the basis of economic allocation. }\end{array}$ & $\mathrm{n} / \mathrm{a}$ & $\begin{array}{l}\text { Concentrate } \mathrm{N} \text { content, electricity, } \\
\text { diesel, methane emission (enteric } \\
\text { fermentation \& manure management). }\end{array}$ & $\begin{array}{l}\text { Leaching of nitrate and phosphate } \\
\text { (farm-gate balance eapproach), } \\
\text { ammonia volatilization (manure in } \\
\text { stable, manure storage, grazing, } \\
\text { application of manure \& fertilizers), } \\
\text { nitrous oxide emission. }\end{array}$ \\
\hline
\end{tabular}


Table A2. Literature review: Nitrogen footprint as a nitrogen efficiency indicator.

\begin{tabular}{|c|c|c|c|c|c|c|}
\hline Reference & $\begin{array}{l}\text { Study } \\
\text { Domain }\end{array}$ & Methodological Scope & Key Features & NUE Value & $\mathrm{N}$ input Values & N output Values \\
\hline $\begin{array}{l}\text { Chatzimpiros \& } \\
\text { Barles } 2013\end{array}$ & Local (France) & $\begin{array}{l}\text { Livestock system for consumption of } \\
\text { dietary } \mathrm{N} \text { in the form of beef, pork and } \\
\text { fresh milk in France. }\end{array}$ & $\begin{array}{l}\text { 1. N Food-print: N loss associated with its } \\
\text { agricultural production. 2. Uses the } \mathrm{N} \text { Food-print } \\
\text { to connect N flows and losses in livestock systems } \\
\text { to the consumption of dietary } \mathrm{N} \text { in the form of } \\
\text { beef, pork and fresh milk. 3. Weight the amount } \\
\text { of consumption proportionally to French } \\
\text { adminisistrative regions' share in the national gross } \\
\text { meat and milk production; foreign countries: } \\
\text { proportionally to their share in national trade } \\
\text { balances. }\end{array}$ & $\begin{array}{l}\text { 1. Feed crop cultivation on the } \\
\text { livestock farms: Beef (76\%) Milk } \\
\text { (76\%) Pork (62\%). 2. Rapeseed } \\
\text { Farms: Milk (40\%) Cereal Farms: } \\
\text { Pork (63\%), Soybean Farms: Beef } \\
\text { (50\%). 3. Overall NUE in ration } \\
\text { production: Beef (72\%) Milk (56\%) } \\
\text { Pork (53\%) 4. Overall NUE per } \\
\text { livestock system: Beef }(7.2 \%) \text { Milk } \\
\text { (13.4\%) Pork (12.7\%). }\end{array}$ & $\begin{array}{l}\text { 1. Feed } \mathrm{N}-\text { roughages (grasses and } \\
\text { legumes), annual fodder (maize, } \\
\text { beetroots, cereals and protein meals } \\
\text { from soybeans/rapeseed crops). } 2 . \mathrm{N} \\
\text { return in manure to fodder crops. } 3 . \mathrm{N} \\
\text { losses from livestock farms (fodder } \\
\text { land on the livestock farms). }\end{array}$ & $\begin{array}{l}\text { 1. } \mathrm{N} \text { in animal product and } \\
\text { by-products (slaughter waste, as well). } \\
2 . \mathrm{N} \text { manure to crop agriculture. }\end{array}$ \\
\hline $\begin{array}{l}\text { Leach et al., } \\
2012\end{array}$ & $\begin{array}{l}\text { National } \\
\text { (United States, } \\
\text { Netherlands) }\end{array}$ & $\begin{array}{l}\text { Per capita nitrogen footprint including } \\
\text { housing energy, transport, food } \\
\text { consumption \& production, and goods and } \\
\text { services. }\end{array}$ & $\begin{array}{l}\text { 1. The food sector is the largest contributor to } \\
\text { personal nitrogen foottprints, sespecially food } \\
\text { production. 2. Dietary choices influence the food } \\
\text { nitrogen footprint; meat and dairy products have } \\
\text { a larger nitrogen footprint than vegetable protein } \\
\text { sources. }\end{array}$ & $\begin{array}{l}\text { Farm-level data reported as virtual } \\
\mathrm{N} \text { factors, which describe the } \mathrm{N} \\
\text { losses during food production by } \\
\text { food category. }\end{array}$ & $\begin{array}{l}\text { Fertilizer, manure and BNF inputs, feed } \\
\text { for livestock. }\end{array}$ & $\begin{array}{l}\text { Food produced, losses to the } \\
\text { environment at each stage of food } \\
\text { production. }\end{array}$ \\
\hline Leip et al., 2014 & $\begin{array}{l}\text { Regional } \\
\text { (European } \\
\text { Union) }\end{array}$ & $\begin{array}{l}\text { 1. Two different models (CAPRI \& } \\
\text { MITERRA) were used to quantify the N } \\
\text { flows in agriculture in the European Union, } \\
\text { at country-level and for EU agriculture as a } \\
\text { whole, differentiated into } 12 \text { main food } \\
\text { categories. 2. Did not include wastage that } \\
\text { occurs during further processing, retail or } \\
\text { preparation of food products. }\end{array}$ & $\begin{array}{l}\text { 1. } \mathrm{N} \text { footprint, defined as total } \mathrm{N} \text { losses to the } \\
\text { environment per unit of product, varies widely } \\
\mathrm{b} / \mathrm{w} \text { different food categories with substantially } \\
\text { higher values for livestock products (c. } 500 \mathrm{~g} \\
\mathrm{~N} / \mathrm{kg} \text { beef) as compared to vegetable products (c. } \\
2 \mathrm{~g} \mathrm{~N} / \mathrm{kg} \text { product for sugar beet, fruits and } \\
\text { vegetables, and potatoes). } 2 \text {. Did not consider fish } \\
\text { and seafood products. 3. Agriciltural sub-pools } \\
\text { considered: livestock production systems, } \\
\text { manure management systems, soil cultivations } \\
\text { systems, and links to human society } \\
\text { (consumption, trade) and environment. }\end{array}$ & $\begin{array}{l}\text { N footprint: Vegetables: } 4.5-6.3 ; \\
\text { Livestock Products: } 63.5-64.7 ; \\
\text { Food products: } 31.5-33.1 .\end{array}$ & $\begin{array}{l}\text { Crop residues; fertilizer; atmospheric } \\
\text { deposition, biological N-fixation. }\end{array}$ & $\begin{array}{l}\text { Losses dominated by } N \text { leaching and } \\
\text { run-off, and ammmonia volatilization. } N \\
\text { outputs: product for which } N \text { footprint } \\
\text { was calculated;'waste' streams that are } \\
\text { recycled; slaughter house waste; } \\
\text { manure. }\end{array}$ \\
\hline Oita et al., 2016 & Global & $\begin{array}{l}\text { N emission flows embodied in } \\
\text { international trade using a high-resolution } \\
\text { global Multi-Region Input-Output (MRIO) } \\
\text { database for } 189 \text { countries }\end{array}$ & $\begin{array}{l}\text { 1. Connect the IPCC's model for the global } \mathrm{N} \\
\text { cycle with data on emissions of all forms of } \mathrm{Nr} \text { to } \\
\text { generate a complete account of emissions for } 189 \\
\text { countries \& } 15,000 \text { industry sectors. } 2 \text {. Of the } \\
117,000 \mathrm{Gg} \text { of } \mathrm{N} \text { emitted worldwide, } 25 \% \text { of the } \\
\text { total became embodied in international trade. } \\
3 \text {. Traded } \mathrm{N} \text { amounts vary significantly across } \\
\text { countries. } 4 \text {. Main net exporters are often } \\
\text { developing countries and net importers are } \\
\text { almost exclusively developed countries. }\end{array}$ & $\begin{array}{l}117,000 \mathrm{Gg} \text { of } \mathrm{N} \text { emitted } \\
\text { worldwide per year. }\end{array}$ & $\begin{array}{l}\text { Crop production, livestock manure, } \\
\text { fertilizers, harvest area ( } 161 \text { crops, } 215 \\
\text { countries); deposition; crop residues. }\end{array}$ & $\begin{array}{l}\text { Emission to water and air: manure } \\
\text { management, emissions to soil, surface } \\
\text { water and underground water; } \\
\text { Mineralization, leaching, } \\
\text { denitrification. }\end{array}$ \\
\hline
\end{tabular}




\section{Table A2. Cont.}

\begin{tabular}{|c|c|c|c|c|c|c|}
\hline $\begin{array}{l}\text { Pierer et al., } \\
\quad 2014\end{array}$ & $\begin{array}{l}\text { National } \\
\text { (Austria) }\end{array}$ & $\begin{array}{l}\text { 1. Footprints describe Nr losses, but do not } \\
\text { link to effects. 2. Food production virtual N: } \\
\text { real losses of Nr along the entire production } \\
\text { and consumption chain (fertilizer } \\
\text { application to final consumption). 3. Food } \\
\text { production energy N: N loss associated } \\
\text { with processes such as packaging and } \\
\text { transportation; combustion-related } \\
\text { emissions of NOx. 4. Food consumption N: } \\
\text { all N consumed as food is excreted. }\end{array}$ & $\begin{array}{l}\text { 1. Total } \mathrm{N} \text { footprint dominated by food } \\
\text { production \& consumption }(85 \%) \text {. } 2 \text {. Avg. } \mathrm{N} \\
\text { Footprint: } 19.8 \mathrm{~kg} \mathrm{~N} / \mathrm{yr} \text { per Austrian inhabitant. } \\
\text { 3. Do not account for co-production; no allocation. } \\
\text { 4. Compared } \mathrm{N} \text { footprints to simple mass of food } \\
\text { and protein content. Ex: vegetables \& fruits as } \\
\text { well as potatoees have very low } \mathrm{N} \text { footprints per } \\
\text { mass, but relatively high footprints per amount of } \\
\text { protein. 5. Do not include fish or seafood. }\end{array}$ & $\begin{array}{l}\text { Poultry: } 24 \% \text { Pork: } 18 \% \text { Beef: } 11 \% \\
\text { Milk: } 16 \% \text { Cereals: } 45 \% \text { Vegetables } \\
\text { \& fruits: } 19 \% \text { Potatoes: } 33 \% \\
\text { Legumes: } 72 \% .\end{array}$ & $\begin{array}{l}\text { Applied } \mathrm{N}, \mathrm{N} \text { in harvested crop, } \mathrm{N} \text { in } \\
\text { the product after first raw processing, } \\
\mathrm{N} \text { in the product after second } \\
\text { processing and packaging, } \mathrm{N} \text { in meat } \\
\text { product, } \mathrm{N} \text { in milk product, } \mathrm{N} \text { available } \\
\text { as feed for animals, } \mathrm{N} \text { in live animal, } \mathrm{N} \\
\text { in slaughtered animal. }\end{array}$ & $\begin{array}{l}\mathrm{N} \text { not taken up by crop, crop } \\
\text { processing waste, handling \& storage, } \\
\text { processing waste, retail food waste, } \\
\text { consumer food waste, food preparation } \\
\text { waste, } N \text { excreted, slaughter waste. }\end{array}$ \\
\hline $\begin{array}{l}\text { Stevens et al., } \\
2014\end{array}$ & $\begin{array}{c}\text { National } \\
\text { (United } \\
\text { Kingdom) }\end{array}$ & $\begin{array}{l}\text { 1. Food N Footprint: sum of the food } \\
\text { consumption and food production } \mathrm{N} \\
\text { footprint. N parameters: available } \mathrm{N}, \% \text { of } \\
\text { previous } \mathrm{N} \text { available, } \mathrm{N} \text { waste produced, } \% \\
\mathrm{~N} \text { recycled, } \mathrm{N} \text { recycled, and } \mathrm{N} \text { loss. } \\
\text { 2. Energy } \mathrm{N} \text { Footprint: housing and } \\
\text { transport energy consumption, NOx } \\
\text { emission factors, Environmental Extended } \\
\text { Input Output analysis for food, housing, } \\
\text { transport, goods and services. }\end{array}$ & $\begin{array}{l}\text { UK N-Calculator used to test scenarios that } \\
\text { would be affected by changes in consumption } \\
\text { patterns: : (1) Recommended protein; (2) } \\
\text { Vegetarian diet; (3) 50\% food waste; (4) } \\
\text { Sustainable food; (5) Advanced wastewater } \\
\text { treatment plant; (6) renewable energy; (7) Public } \\
\text { transit, (8) Combination (\#1-7). }\end{array}$ & $\begin{array}{l}\text { N Footprint: } 27.1 \mathrm{~kg} \mathrm{~N} \text { per capita } \\
\text { per year. }\end{array}$ & $\begin{array}{l}\text { Applied } \mathrm{N}, \mathrm{N} \text { in harvested crop, } \mathrm{N} \text { in } \\
\text { product after processing, packaging, } \mathrm{N} \\
\text { in meat production, } \mathrm{N} \text { in animal } \\
\text { by-products, } \mathrm{N} \text { in live animal, } \mathrm{N} \text { in } \\
\text { slaughtered animals. }\end{array}$ & $\begin{array}{l}\mathrm{N} \text { not taken up by crop, crop } \\
\text { processing waste, handling \& storage, } \\
\text { processing waste, retail food waste, } \\
\text { consumer food waste, food preparation } \\
\text { waste, } \mathrm{N} \text { excreted, slaughter waste. }\end{array}$ \\
\hline
\end{tabular}


Table A3. Literature review: Nitrogen budget as a nitrogen efficiency indicator.

\begin{tabular}{|c|c|c|c|c|c|c|}
\hline Reference & Study Domain & Methodological Scope & Key Features & NUE Value & $\mathrm{N}$ input Values & N output Values \\
\hline $\begin{array}{l}\text { Bleken and } \\
\text { Bakken } 1997\end{array}$ & National (Norway) & $\begin{array}{l}\text { Estimation of the } \mathrm{N} \text { efficiency of } \\
\text { the food producing sector in } \\
\text { Norway, including the overall } \\
\text { production system as well as } \\
\text { specific products. }\end{array}$ & $\begin{array}{l}\text { 1. The food producing sector is the } \\
\text { largest } \mathrm{N} \text {-flow sector in Norway. } \\
2 \text {. N-cost is defined as the ratio } \\
\text { between fertilizer } \mathrm{N} \text {-input and the } \mathrm{N} \text { in } \\
\text { products. 3. Recycling of wastes and } \\
\text { dietary changes are key mitigation } \\
\text { efforts. }\end{array}$ & Norway NUE $=10 \%$ & $\begin{array}{l}\text { Synthetic fertilizer, biological fixation, } \\
\text { atmospheric deposition, feed. }\end{array}$ & $\begin{array}{l}\text { Wholesale food supply, food waste, } \\
\text { sewage, trade export. }\end{array}$ \\
\hline $\begin{array}{l}\text { Dalgaard et al., } \\
2012\end{array}$ & $\begin{array}{l}\text { National/Regional (Poland, } \\
\text { the Netherlands, France, } \\
\text { Italy, Scotland, Denmark) }\end{array}$ & $\begin{array}{l}\text { 1. Analyses farm N-losses and the } \\
\text { complex interactions within } \\
\text { farming systems by developing } \\
\text { efficient methods for identifying } \\
\text { emissions hotspots and evaluating } \\
\text { mitigation measures at the farm } \\
\text { and landscape scale. } 2 \text {. Farm } \mathrm{N} \\
\text { balance defined as from the farm } \\
\text { gate, including N inputs to the } \\
\text { farm, and N outputs from the farm. }\end{array}$ & $\begin{array}{l}\text { 1. Developed a common method to } \\
\text { undertake farm inventories and the } \\
\text { derivation of farm } \mathrm{N} \text { balances, } \mathrm{N} \\
\text { surpluses and for evaluating } \\
\text { uncertainty for the } 222 \text { farms and } \\
11,440 \text { ha of farmland. } 2 \text {. Results } \\
\text { showed farm } \mathrm{N} \text { surpuluses may be used } \\
\text { as an independent dataset for } \\
\text { validation of measured and modelled } \\
\mathrm{N} \text { emissions in agricultural landscapes. }\end{array}$ & $\mathrm{n} / \mathrm{a}$ & $\begin{array}{l}\text { Fodder: } \mathrm{N} \text { in imported fodder and } \\
\text { seed, minus N in cash crops sold, } \\
\text { fertilizer: } \mathrm{N} \text { imported in synthetic } \\
\text { fertilizer and animal manure, } \\
\text { deposition: atmospheric deposition } \\
\text { and biological } \mathrm{N} \text { fixation. }\end{array}$ & $\begin{array}{l}\text { Milk and other animal produce (incl. } \\
\text { meat, live animals, eggs and wool). }\end{array}$ \\
\hline $\begin{array}{l}\text { Galloway and } \\
\text { Cowling } 2002\end{array}$ & Global & $\begin{array}{l}\text { Overall } \mathrm{N} \text { efficiency of plant and } \\
\text { animal production, starting with } \\
\text { the input of } \mathrm{N} \text { to a crop field and } \\
\text { ending with the final food product. }\end{array}$ & $\begin{array}{l}\text { 1. Global average NUE is } 14 \% \text { for plant } \\
\text { products and } 4 \% \text { for animal products. } \\
2 \text {. Most of } \mathrm{N} \text { used in food production is } \\
\text { lost to the environment. }\end{array}$ & $\begin{array}{l}\text { Global NUE }=14 \% \text { for plant } \\
\text { products and } 4 \% \text { for animal } \\
\text { products. }\end{array}$ & $\begin{array}{l}\mathrm{N} \text { fertilizer or other input applied to } \\
\text { a crop field, feed. }\end{array}$ & $\begin{array}{l}\text { Food product, } \mathrm{N} \text { loss at each stage of } \\
\text { production. }\end{array}$ \\
\hline $\begin{array}{l}\text { Grizzetti et al., } \\
\quad 2013\end{array}$ & Global and regional (Europe) & $\begin{array}{l}\text { 1. Quantifies } \mathrm{N} \text { losses to the } \\
\text { environment related to food waste } \\
\text { at consumption at the global and } \\
\text { European scale. } 2 \text {. Analyses its } \\
\text { relative impact on the } \\
\text { environment. }\end{array}$ & $\begin{array}{l}\text { 1. } 7 \text { regions: (1) Europe (2) USA, } \\
\text { Canada \& Oceania (3) Industrialized } \\
\text { Asia (4) Sub-Saharan Africa (5) North } \\
\text { Africa, Westand Central Asia (6) South } \\
\text { \& South-East Asia (7) Latin America. } \\
\text { 2. Food Groups: (1) Cereals (2) roots } \\
\text { and tubers (3) oilseed \& Pulses (4) fruit } \\
\text { and vegetables (5) meat (6) fish and } \\
\text { seafood (7) milk. 3. Applied virtual N } \\
\text { and N footprint concept to quantify the } \\
\text { amount of N delivered to the } \\
\text { environment that is related to the } \\
\text { production of food then wasted. }\end{array}$ & $\begin{array}{l}\mathrm{n} / \mathrm{a} 9 \% \text { of the total nitrogen } \\
\text { food supply is lost to } \\
\text { environment; } 2 \% \text { of the global } \\
\text { annual input of synthetic } \mathrm{N} \\
\text { fertilizer. }\end{array}$ & Total $\mathrm{N}$ in food at consumption. & $\begin{array}{l}\text { Amount of } \mathrm{N} \text { lost or wasted at } \\
\text { consumption. }\end{array}$ \\
\hline $\begin{array}{l}\text { Gustavsson et al., } \\
\quad 2011\end{array}$ & Global & $\begin{array}{l}\text { 1. Losses occurring along the entire } \\
\text { food system (food intended for } \\
\text { human consumption). } 2 \text {. Assesses } \\
\text { magnitude of food loss, mass flows. } \\
\text { 3. Identifies causes \& prevention } \\
\text { methods. }\end{array}$ & $\begin{array}{l}\text { 1. Roughly } 1 / 3 \text { of food produced for } \\
\text { human consumption is lost or wasted } \\
\text { globally ( } 1.3 \text { billion tons). } 2 \text {. On a } \\
\text { per-capita basis, more food is wasted in } \\
\text { the industrialized world than in } \\
\text { developing countries: Developing } \\
\text { countries have greater food losses in } \\
\text { the first tsteps of the FSC. Developed } \\
\text { countries have greater food losses at } \\
\text { the retail and consumption levels. } \\
\text { 3. Study revealed major data gaps in } \\
\text { the knowledge of global food loss and } \\
\text { waste. }\end{array}$ & $\mathrm{n} / \mathrm{a}$ & $\begin{array}{l}\text { 1. N LOSSES: Vegetable } \\
\text { Commodities \& Products. } \\
\text { 2. Agriciltural production: losses } \\
\text { due to mechanical damage and /or } \\
\text { spillage during harvest operation, } \\
\text { crops sorted postharvest, etc. } \\
\text { 3. Postharvest handling \& storage: } \\
\text { losses due to spillage, degradation } \\
\text { during handling, storage and } \\
\text { transportation b/ w farm and } \\
\text { distribution. 4. Processing: losses } \\
\text { due to spillage during industrial or } \\
\text { domestic processing. 5. Distribution: } \\
\text { losses and waste in the market } \\
\text { system. 6. Consumption: losses and } \\
\text { waste during consumption at the } \\
\text { household level. }\end{array}$ & $\begin{array}{l}\text { 1. N LOSSES: Animal Commodities \& } \\
\text { Products. 2. Agricultural Production: } \\
\text { animal death during breeding, discards } \\
\text { during fishing, decreased production due } \\
\text { to animal sickness. . Postharvest } \\
\text { handling \& storage: death during } \\
\text { transport to slaughter and condemnation } \\
\text { at slaughterhouse. Spillage and } \\
\text { degradation during packaging, storage } \\
\text { and transportation. 4. Processing: } \\
\text { trimming spillage during slaughtering } \\
\text { and losses during industrial processing. } \\
\text { 5. Distribution: losses and waste in the } \\
\text { market system. . Consumption: losses } \\
\text { and waste during consumption at the } \\
\text { household level. }\end{array}$ \\
\hline
\end{tabular}


Table A3. Cont.

\begin{tabular}{|c|c|c|c|c|c|c|}
\hline $\begin{array}{l}\text { Howarth et al., } \\
2002\end{array}$ & National (USA) & $\begin{array}{l}\text { Anthropogenic nitrogen budget for } \\
\text { the United States, including food } \\
\text { and energy production and } \\
\text { consumption. }\end{array}$ & $\begin{array}{l}\text { 1. About } 50 \% \text { of new reactive } \mathrm{N} \text { inputs } \\
\text { to agricultural fields are removed as } \\
\text { harvested crops. Most of these crops go } \\
\text { towards livestock feed. } 2.15 \% \text { of crop } \\
\text { harvest } \mathrm{N} \text { is consumed directly by } \\
\text { humans, and about } 70 \% \text { goes towards } \\
\text { livestock feed. } 3 \text {. About } 5 \% \text { of the new } \\
\text { reactive } \mathrm{N} \text { inputs to agricultural feeds } \\
\text { for animal protein production is } \\
\text { consumed by humans. }\end{array}$ & $\begin{array}{l}\text { USA NUE }=15 \% \text { for plant } \\
\text { protein and } 5 \% \text { for animal } \\
\text { protein. }\end{array}$ & $\begin{array}{l}\text { Inorganic } \mathrm{N} \text { fertilizer, } \mathrm{N} \text { fixation in } \\
\text { agricultural systems, NOx emissions } \\
\text { from fossil fuel combustion. }\end{array}$ & $\begin{array}{l}\text { Export in rivers, food and feed export, } \\
\text { atmospheric advection to oceans, } \\
\text { denitrification and storage. }\end{array}$ \\
\hline $\begin{array}{l}\text { Isermann and } \\
\text { Isermann } 1998\end{array}$ & National (Germany) & $\begin{array}{l}\text { Country-level } \mathrm{N} \text { balance for food } \\
\text { and feed production and } \\
\text { consumption. }\end{array}$ & $\begin{array}{l}\text { 1. The production and consumption of } \\
\text { food and feed in Germany is } 50 \% \\
\text { higher than what is needed for basic } \\
\text { nutrition needs. 2. Inefficiency leads to } \\
\mathrm{N} \text { losses to the hydrosphere and } \\
\text { atmosphere that were } 2-8 \text { times too } \\
\text { high. 3. Propose a need-oriented } \\
\text { production food } \\
\text { production/consumption system. }\end{array}$ & Germany NUE $=10 \%$ & $\begin{array}{l}\text { Atmospheric deposition, biological } \\
\text { fixation, sewage sludge, biocomposts, } \\
\text { imported feeds, net mineralization, } \\
\text { mineral fertilizer, manure. }\end{array}$ & $\begin{array}{l}\text { Removal by biomass; surplus to the } \\
\text { pedosphere, atmosphere, and } \\
\text { hydrosphere; leaching; volatilization. }\end{array}$ \\
\hline $\begin{array}{l}\text { Lassaletta et al., } \\
\qquad 2014\end{array}$ & Global & $\begin{array}{l}\text { 1. Analyses the importance of } \\
\text { international trade of food and } \\
\text { feed in the alteration of the } \mathrm{N} \text { cycle } \\
\text { at the global scale. } 2 \text {. Assigned } \mathrm{N} \\
\text { content to every product }(407 \\
\text { vegetables, } 128 \text { animal products) } \\
\text { with data from different literature } \\
\text { sources. 3. Calculated total net } \\
\text { importer and exporter values for } \\
\text { all } 210 \text { countries. }\end{array}$ & $\begin{array}{l}\text { 1. Used information on food and feed } \\
\text { trade, and assumed that } N \text { constitutes } \\
16 \% \text { of proteins to quantify the } N \\
\text { traded annually during } 1961-2010 \text {. } \\
2 \text {. Amount of } N \text { traded between } \\
\text { countries increased eightfold, now } \\
\text { concerns } 1 / 3 \text { of the total } N \text { in world } \\
\text { crop production. } 3 \text {. Divided world in } \\
12 \text { regions and studied } N \text { transfer in } 2 \\
\text { reference years: } 1986 \text { \& } 2009 \text {. } 4 \text {. A small } \\
\text { number of countries, with regard to } \\
\text { proteins, are feeding the rest of the } \\
\text { world. 5. Globally, system is becoming } \\
\text { less efficient - disconnect b/w crop and } \\
\text { livestock production across regions }\end{array}$ & $\begin{array}{l}\text { n/a Net importer and exporter } \\
\text { status varies by country. }\end{array}$ & $\mathrm{N}$ contained in imported products. & $\mathrm{N}$ contained in exported products. \\
\hline Leip et al., 2011 & $\begin{array}{l}\text { Regional (Europe, EU27 } \\
\text { countries) }\end{array}$ & $\begin{array}{l}\text { Farm, land and soil N-budgets for } \\
\text { countries in Europe and the EU27 } \\
\text { using agro-economic model } \\
\text { CAPRI. }\end{array}$ & $\begin{array}{l}\text { 1. CAPRI: global economic model for } \\
\text { agriculture with a regionalized focus } \\
\text { for Europe. } 2 \text {. Farm N budget is } \\
\text { constructed by a combination of the } \\
\text { market and animal balances. 3. Market } \\
\text { Balances: captures market appearances } \\
\text { from domestic production and imports, } \\
\text { and their distribution to various } \\
\text { domestic uses and exports. } 4 \text {. Animal } \\
\text { Balance: calculates inputs of N by feed } \\
\text { and the output in animal products. }\end{array}$ & $\begin{array}{l}\text { Farm N budget NUE: } 31 \% \\
\text { (varies from } 15 \% \text { Ireland- }-50 \% \\
\text { Romania) Land N budget } \\
\text { NUE: } 60 \% \text { Soil N budget NUE: } \\
63 \% .\end{array}$ & $\begin{array}{l}\text { Manure (application): accounts for } \\
\text { losses from housing \& management; } \\
\mathrm{N} \text { content of crops; N intake of crude } \\
\text { protein; Feed (concentrates); Crop } \\
\text { residues returned; Biological N } \\
\text { fixation; Atmospheric deposition; } \\
\text { Mineral fertilizer. }\end{array}$ & $\begin{array}{l}\text { Manure (excretion): includes leaching, } \\
\text { runoff \& gaseous emissions; Product } \\
\text { output (milk or meat); Sold crop } \\
\text { products; Fodder; Crop residues; Soil } \\
\text { N-stock changes; Leaching, runoff, and } \\
\text { gaseous emissions before manure. }\end{array}$ \\
\hline
\end{tabular}


Table A3. Cont.

\begin{tabular}{|c|c|c|c|c|c|c|}
\hline Ma et al., 2010 & National (China) & $\begin{array}{l}\text { Nutrient flows (nitrogen and } \\
\text { phosphorus) along the entire food } \\
\text { system. }\end{array}$ & $\begin{array}{l}\text { 1. The NUFER model (NUtrient flows } \\
\text { in Food systems, Environment and } \\
\text { Resources use) tracks } \mathrm{N} \text { and } \mathrm{P} \\
\text { efficiencies and losses at a national } \\
\text { scale. } 2 \text {. Links to species of } \mathrm{N} \text { lost to the } \\
\text { environment (ammonia, nitrous oxide, } \\
\text { dinitrogen, and nitrogen oxides). } 3 . \mathrm{N} \\
\text { and P efficiency can be improved with } \\
\text { increased production, balanced } \\
\text { fertilization, and improved manure } \\
\text { management. }\end{array}$ & $\begin{array}{l}\text { China N use efficiency for crop } \\
\text { production }(26 \%) \text {, animal } \\
\text { production }(11 \%) \text {, and the } \\
\text { whole food chain }(9 \%) \text {. }\end{array}$ & $\begin{array}{l}\text { Fertilizer inputs, crop yields and } \\
\text { areas, number of animals, consumer } \\
\text { diets, harvested crop and animal } \\
\text { product nutrient content, rate and } \\
\text { content of animal excretion. }\end{array}$ & $\begin{array}{l}\text { Regional } \mathrm{N} \text { and } \mathrm{P} \text { flows, use efficiencies, } \\
\text { and emissions by type. }\end{array}$ \\
\hline $\begin{array}{l}\text { Godinot et al., } \\
2016\end{array}$ & Regional (Europe) & $\begin{array}{l}\text { Applies three new proposed farm } \\
\text { nitrogen indicators at the European } \\
\text { scale: system N efficiency (SyNE), } \\
\text { relative N efficiency (RNN), and } \\
\text { system N balance (SyNB). }\end{array}$ & $\begin{array}{l}\text { 1. The farm NUE and FGB do not } \\
\text { adequately account for all nitrogen } \\
\text { flows in systems. 2. Proposed } \\
\text { indicators (SyNE and SyNB) better } \\
\text { account for indirect N losses. 3. RNE } \\
\text { compares the actual N efficiency to an } \\
\text { attainable N efficiency, which can } \\
\text { identify how much N efficiency can be } \\
\text { improved on a given farm. }\end{array}$ & $\begin{array}{l}\text { European NUE is } 0.35 \text { and } \\
\text { Farm-Gate Balance (FGB) is } 86 \\
\mathrm{~kg} \mathrm{~N} / \mathrm{ha} \text {, whereas the SyNE is } \\
0.23 \text { and SyNB is } 113 \mathrm{~kg} \mathrm{~N} / \mathrm{ha} \text {. } \\
\text { Mean RNE is } 0.43 \text {. }\end{array}$ & $\begin{array}{l}\text { 1. NUE and FGB: Inorganic } \\
\text { fertilizers, manure, fixation, } \\
\text { atmospheric deposition, crops, } \\
\text { animals, energy. 2. SyNE and SynB: } \\
\text { Inorganic fertilizers, manure, fixation, } \\
\text { atmospheric deposition, crops, } \\
\text { animals, energy, indirect losses. } \\
\text { 3. RNE: SyNE divided by an } \\
\text { attainable efficiency. }\end{array}$ & $\begin{array}{l}\text { 1. NUE and FGB: Crops, animal products, } \\
\text { manure. 2. SyNE and SyNB: Crops, } \\
\text { animal products, manure. } 3 \text { RNE: SyNE } \\
\text { divided by an attainable efficiency. }\end{array}$ \\
\hline Oenema 2003 & Varies & $\begin{array}{l}\text { 1. Explores nutrient budgeting } \\
\text { approaches and summarizes } \\
\text { sources of uncertainty associated } \\
\text { with these approaches. } 2 \text {. } \\
\text { Implications of uncertainties are } \\
\text { discussed. }\end{array}$ & 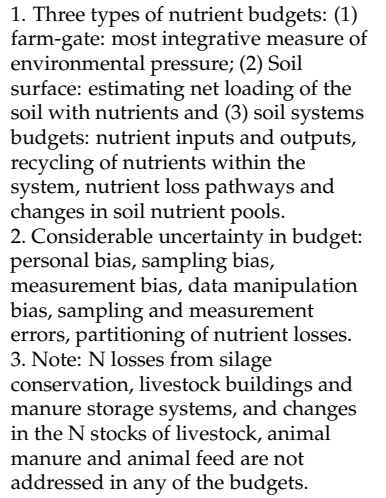 & $n / a$ & $\begin{array}{l}\text { 1. Farm-gate budget: fertilizer, feed, } \\
\text { manure, cattle, bedding material, } \\
\text { Biological N fixation, atmospheric } \\
\text { deposition. . Soil surface budget: } \\
\text { fertilizer, urine and dung deposition, } \\
\text { manure, forage losses, BNF, } \\
\text { atmospheric deposition. 3. Soil } \\
\text { system budget: fertilizer, urine and } \\
\text { dung depositions, manure, forage } \\
\text { losses, BNF, atmospheric deposition. }\end{array}$ & $\begin{array}{l}\text { 1. Farm-gate budget: milk, cattle, animal } \\
\text { manure, animal feed. 2. Soil surface } \\
\text { budget: harvested grass by grazing } \\
\text { animals, harvest silage maize \& grass. } \\
\text { 3. Soil system budget: harvested grass, } \\
\text { harvest silage maize \& grass, ammonia } \\
\text { volatilization from dung \& urine, } \\
\text { manure, and forages, denitrification, } \\
\text { leaching and runoff, net immobilization. }\end{array}$ \\
\hline
\end{tabular}




\section{Table A3. Cont.}

\begin{tabular}{|c|c|c|c|c|c|c|}
\hline Oenema 2006 & Varies & $\begin{array}{l}\text { Reviews } \mathrm{N} \text { input-output budgets } \\
\text { and N losses in livestock farming } \\
\text { systems. }\end{array}$ & $\begin{array}{l}\text { 1. Generally, } \mathrm{N} \text { inputs and losses } \\
\text { increase in the order grazing systems < } \\
\text { mixed systems < land-less systems. } \\
\text { 2. Difficulties of establishing N budgets } \\
\text { arise from the tendency of } \mathrm{N} \text { to } \\
\text { dissipate into the wider environment in } \\
\text { a variety of species, including gaseous } \\
\mathrm{N} \text { species. } 3 \text {. Standardization of } \\
\text { methodologies is required to allow } \\
\text { comparison of budgets. 4. Improve } \\
\text { utilization of animal manure as } \\
\text { fertilizer and manure management in } \\
\text { general. }\end{array}$ & $\mathrm{n} / \mathrm{a}$ & $\begin{array}{l}\text { Feed, fertilizer, deposition, biological } \\
\text { fixation. }\end{array}$ & $\begin{array}{l}\text { Milk, meat, manure export, ammonia } \\
\text { loss, denitrification, leaching. }\end{array}$ \\
\hline Parfitt et al., 2010 & Global & $\begin{array}{l}\text { Review of literature on food waste } \\
\text { throughout the supply chain in } \\
\text { developing, transitional, and } \\
\text { developed countries. }\end{array}$ & $\begin{array}{l}\text { Food waste is highest at the immediate } \\
\text { post-harvest level in developing } \\
\text { countries and the post-consumer level } \\
\text { in developed countries. }\end{array}$ & $n / a$ & $n / a$ & $n / a$ \\
\hline $\begin{array}{l}\text { Shindo et al., 2003; } \\
2006\end{array}$ & Regional (East Asia) & $\begin{array}{l}\text { Report the } \mathrm{N} \text { load for East Asian } \\
\text { countries using a budget approach, } \\
\text { including } \mathrm{N} \text { from biological } \\
\text { fixation, energy production, } \\
\text { human waste, and farmland. }\end{array}$ & $\begin{array}{l}\text { 1. Food production contributed more } \\
\text { than } 90 \% \text { of the nitrogen load in East } \\
\text { Asia. Fossil fuel } \mathrm{N} \text { was only significant } \\
\text { in Japan and South Korea. } 2 \text {. N load } \\
\text { was reported by sector as the difference } \\
\text { between } \mathrm{N} \text { input and } \mathrm{N} \text { uptake. }\end{array}$ & $\begin{array}{l}\text { East Asia NUE has a large } \\
\text { range. }\end{array}$ & $\begin{array}{l}\text { Fertilizer consumption, food balance } \\
\text { sheets. }\end{array}$ & $\begin{array}{l}\text { Food production and consumption, NOx } \\
\text { emissions by region, N losses to } \\
\text { waterways, denitrification, organic } \\
\text { matter accumulation. }\end{array}$ \\
\hline $\begin{array}{l}\text { Westhoek et al., } \\
\quad 2014\end{array}$ & Regional (Europe) & $\begin{array}{l}\text { The environmental impacts } \\
\text { (nitrogen emissions, greenhouse } \\
\text { gas emissions, and cropland) and } \\
\text { health effects of } 6 \text { alternative diets } \\
\text { with reduced meat \& dairy were } \\
\text { reviewed. }\end{array}$ & $\begin{array}{l}\text { 1. Nitrogen emissions could be reduced } \\
\text { by } 40 \% \text { from reductions in meat and } \\
\text { dairy intake. 2. A variety of data sets } \\
\text { and models were used to assess } \\
\text { nitrogen inputs and emissions across } \\
\text { the US. Resources include FAO for } \\
\text { dietary data and the GAINS model for } \\
\text { livestock excretion rates and N } \\
\text { emissions. }\end{array}$ & $\begin{array}{l}\text { Current Europe NUE }=18 \% \text {. } \\
\text { NUE would increase to } 41-47 \% \\
\text { with meat and dairy reduction } \\
\text { scenarios. }\end{array}$ & $\begin{array}{l}\text { Feed imports, fertilizer, } \mathrm{N} \text { fixation, } \mathrm{N} \\
\text { deposition. }\end{array}$ & $\begin{array}{l}\text { Food produced, food exported, emissions } \\
\text { to air, emissions to groundwater and } \\
\text { surface waters. }\end{array}$ \\
\hline
\end{tabular}


Table A4. Literature review: Environmental impact assessment as a nitrogen efficiency indicator.

\begin{tabular}{|c|c|c|c|c|c|c|}
\hline Reference & Study Domain & Methodological Scope & Key Features & NUE Value & $\mathrm{N}$ input values & $N$ output Values \\
\hline OECD 2001 & Global & $\begin{array}{l}\text { Reviews existing agricultural } \\
\text { environmental indicators and their results } \\
\text { over the last several decades. }\end{array}$ & $\begin{array}{l}\text { 1. A nitrogen-specific indicator for the } \\
\text { environmental impacts of nitrogen does not yet } \\
\text { exist. 2. Existing environmental impact indicators } \\
\text { for agriculture assess soil quality, water quality, } \\
\text { land conservation, greenhouse gases, biodiversity, } \\
\text { wildlife habitats, and landscape. }\end{array}$ & $n / a$ & $n / a$ & $n / a$ \\
\hline $\begin{array}{l}\text { Payraudeau and van der } \\
\text { Werf } 2005\end{array}$ & Global & $\begin{array}{l}\text { Review of six methods for environmental } \\
\text { impact assessment: : Environmental Risk } \\
\text { Mapping (ERM), fife cycle assessment } \\
\text { (LCA), environmental impact assessment } \\
\text { (EIA), multi-agent system (MIA), linear } \\
\text { programming (LP)) agro-environmental } \\
\text { indicators (AEI). }\end{array}$ & $\begin{array}{l}\text { 1. The methods presented all link to } \\
\text { environmental impacts; the authors state that } \\
\text { indicators that link to environmental effects are } \\
\text { preferable over those based on specific farming } \\
\text { practices. 2. Two important metrics are impact per } \\
\mathrm{kg} \text { of product and impact per unit of land area. }\end{array}$ & $n / a$ & $\mathrm{n} / \mathrm{a}$ & $\mathrm{n} / \mathrm{a}$ \\
\hline $\begin{array}{c}\text { Van der Werf \& Petit } \\
2001\end{array}$ & Varies & $\begin{array}{l}\text { Reviewed } 12 \text { methods that use a set of } \\
\text { indicators to evaluate the environmental } \\
\text { impact of agriculture at the farm level. }\end{array}$ & 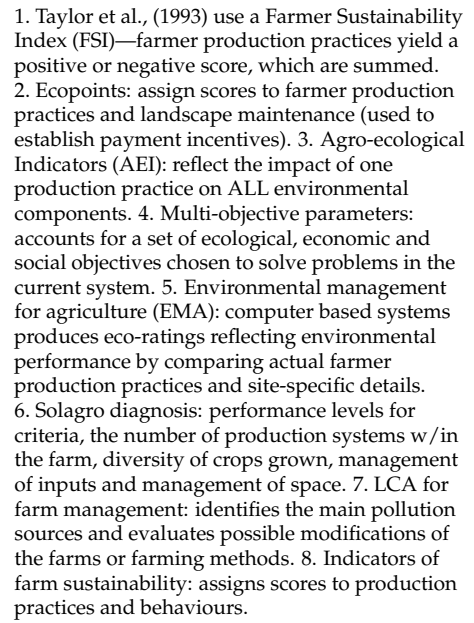 & $n / a$ & $\begin{array}{l}\text { Use of non-renewable energy } \\
\& \text { other non-renewable } \\
\text { resources, land use, water use, } \\
\text { nitrogen fertilizer use, } \\
\text { pesticide use, waste utilization. }\end{array}$ & $\begin{array}{l}\text { Emission of: greenhouse gases, } \\
\text { ozone depleting gases, acidifying } \\
\text { gases, nutritious substances, } \\
\text { pesticides, terrestrial ecotoxicity, } \\
\text { aquatic ecotoxicity, human } \\
\text { toxicity, waste production. }\end{array}$ \\
\hline
\end{tabular}


There are some general gaps and trends across the different approaches. The general gaps in the four approaches are the following (depending on the application whether relevant or not):

- Inconsistency in accounting for exports as a portion of national production.

- Variability in accounting for biological nitrogen fixation (BNF), total soil nitrogen, nitrogen sources, and nitrogen sinks.

- $\quad$ Limited differentiation between new (e.g., synthetic fertilizer) versus recycled (e.g., manure) $\mathrm{N}$ inputs.

- Inconsistency in approaches that address crop rotations, which in most cases is a limitation in calculating crop specific $\mathrm{N}$ use.

- Animal and plant product allocation to different final products at the farm gate. There are a variety of methods for determining how much of the $\mathrm{N}$ use should be allocated toward multiple products.

- For the approaches based on losses, some studies chose to include gaseous emissions to the atmosphere and others did not. Atmospheric nitrogen deposition is often lacking as well as denitrification. In these studies, $\mathrm{N}$ leaching estimation is uncertain and therewith the $\mathrm{N}$ outputs.

- There are limited connections between the $\mathrm{N}$ use results and actual environmental impacts.

\section{References}

1. Sutton, M.A.; Howard, C.M.; Erisman, J.W.; Erisman, J.W.; Billen, G.; Bleeker, A.; Grennfelt, P.; van Grinsven, H.; Grizzetti, B. The European Nitrogen Assessment; Cambridge University Press: Cambridge, UK, 2011.

2. Oenema, O. Nitrogen budgets and losses in livestock systems. Int. Congr. Ser. 2006, 1293, 262-271. [CrossRef]

3. Galloway, J.N.; Townsend, A.R.; Erisman, J.W.; Bekunda, M.; Cai, Z.; Freney, J.R.; Martinelli, L.A.; Seitzinger, S.P.; Sutton, M.A. Transformation of the nitrogen cycle: Recent trends, questions, and potential solutions. Science 2008, 320, 889-892. [CrossRef] [PubMed]

4. Fowler, D.; Coyle, M.; Skiba, U.; Sutton, M.A.; Cape, J.N.; Reis, S.; Sheppard, L.J.; Jenkins, A.; Grizzetti, B.; Galloway, J.N.; et al. The global nitrogen cycle in the twenty-first century. Philos. Trans. R. Soc. Lond. B Boil. Sci. 2013, 368, 20130164. [CrossRef] [PubMed]

5. Galloway, J.N.; Aber, J.D.; Erisman, J.W.; Seitzinger, S.P.; Howarth, R.W.; Cowling, E.B.; Cosby, B.J. The nitrogen Cascade. BioScience 2003, 53, 341-356. [CrossRef]

6. Erisman, J.W.; Galloway, J.N.; Seitzinger, S.; Bleeker, A.; Dise, N.B.; Petrescu, R.; Leach, A.M.; de Vries, W. Consequences of human modification of the global nitrogen cycle. Philos. Trans. R. Soc. Lond. B Boil. Sci. 2013, 368, 20130116. [CrossRef] [PubMed]

7. Sutton, M.A.; Bleeker, A.; Howard, C.M.; Bekunda, M.; Grizzeetti, B.; de Vries, W.; van Grinsven, H.J.M.; Abrol, Y.P.; Adhya, T.K.; Billen, G.E.A.; et al. Our Nutrient World: The Challenge to Produce More Food and Energy with Less Pollution; Centre for Ecology and Hydrology: Edinburgh, UK, 2013; 128p.

8. EU Nitrogen Expert Panel. Nitrogen Use Efficiency (NUE) — Guidance Document for Assessing NUE at Farm Level; Wageningen University: Wageningen, The Netherlands, 2016.

9. Ahlgren, S.; Baky, A.; Bernesson, S.; Nordberg, Å.; Norén, O.; Hansson, P.A. Consequential Life Cycle Assessment of Nitrogen Fertilisers Based on Biomass-A Swedish Perspective. Insci. J. 2012, 2, 80-101. [CrossRef]

10. Brentrup, F.; Kusters, J.; Kuhlmann, H.; Lammel, J. Application of the life cycle assessment methodology to agricultural production: An example of sugar beet production with different forms of Nitrogen Fertilisers. Eur. J. Agron. 2001, 14, 221-233. [CrossRef]

11. Brentrup, F.; Küsters, J.; Lammel, J.; Barraclough, P.; Kuhlmann, H. Environmental impact assessment of agricultural production systems using the Life Cycle Assessment (LCA) methodology II. The application to $\mathrm{n}$ fertilizer use in winter wheat production systems. Eur. J. Agron. 2004, 20, 265-279. [CrossRef]

12. Caffrey, K.R.; Veal, M.W. Conducting an Agricultural Life Cycle Assessment: Challenges and Perspectives. Sci. World J. 2013, 2013. [CrossRef] [PubMed]

13. Cederberg, C.; Mattson, B. Life cycle assessment of milk production: A comparison of conventional and organic farming. J. Clean. Prod. 1999, 8, 49-60. [CrossRef] 
14. Gallejones, P.; Pardo, G.; Aizpurua, A.; del Prado, A. Life cycle assessment of first-generation biofuels using a nitrogen crop model. Sci. Total Environ. 2014, 505, 1191-1201. [CrossRef] [PubMed]

15. Harris, S.; Narayanaswamy, V. A Literature Review of Life Cycle Assessment in Agriculture; Rural Industries Research and Development Corporation: Barton, Australia, 2009; p. 45.

16. Liao, W.; van der Werf, H.M.G.; Salmon-Monviola, J. Improved environmental life cycle assessment of crop production at the catchment scale via a process-based nitrogen simulation model. Environ. Sci. Technol. 2015, 49, 10790-10796. [CrossRef] [PubMed]

17. Pelletier, N.; Leip, A. Quantifying anthropogenic mobilization, flows (in product systems) and emissions of fixed nitrogen in process-based environmental life cycle assessment: Rationale, methods and application to a life cycle inventory. Int. J. Life Cycle Assess. 2014, 19, 166-173. [CrossRef]

18. Thomassen, M.A.; Van Calker, K.J.; Smits, M.C.J.; Iepema, G.L.; De Boer, I.J.M. Life cycle assessment of conventional and organic milk production in The Netherlands. Agric. Syst. 2008, 96, 95-107. [CrossRef]

19. Chatzimpiros, P.; Barles, S. Nitrogen food-print: $\mathrm{N}$ use related to meat and dairy consumption in France. Biogeosciences 2013, 10, 471-481. [CrossRef]

20. Leach, A.M.; Galloway, J.N.; Bleeker, A.; Erisman, J.W.; Kohn, R.; Kitzes, J. A nitrogen footprint model to help consumers understand their role in nitrogen losses to the environment. Environ. Dev. 2012, 1, 40-66. [CrossRef]

21. Stevens, C.J.; Leach, A.J.; Dale, S.; Galloway, J.N. Personal nitrogen footprint tool for the United Kingdom. Environ. Sci. Process. Impacts 2014, 16, 1563-1569. [CrossRef] [PubMed]

22. Pierer, M.; Winiwarter, W.; Leach, A.M.; Galloway, J.N. The nitrogen footprint of food products and general consumption patterns in Austria. Food Policy 2014, 49, 128-136. [CrossRef]

23. Shibata, H.; Cattaneo, L.R.; Leach, A.M.; Galloway, J.N. First approach to the Japanese nitrogen footprint model to predict the loss of nitrogen to the environment. Environ. Res. Lett. 2014, 9, 11503. [CrossRef]

24. Shibata, H.; Galloway, J.N.; Leach, A.M.; Noll, C.; Erisman, J.W.; Erisman, J.W.; Gu, B.; Liang, X.; Hayashi, K.; Ma, L.; et al. Nitrogen footprints: Regional realities and options to reduce nitrogen loss to the environment. Ambio 2017, 46, 129-142. [CrossRef] [PubMed]

25. Galloway, J.N.; Winiwarter, W.; Leip, A.; Leach, A.M.; Bleeker, A.; Erisman, J.W. Nitrogen footprints: Past, present and future. Environ. Res. Lett. 2014, 9, 115003. [CrossRef]

26. Bleken, M.A.; Bakken, L.R. The nitrogen cost of food production: Norwegian society. Ambio 1997, 26, 130-135.

27. Dalgaard, T.; Bienkowski, J.F.; Bleeker, A.; Dragosits, U.; Drouet, J.L.; Durand, P.; Frumau, A.; Hutchings, N.J.; Kedziora, A.; Magliulo, V.; et al. Farm Nitrogen Balances in Six European Landscapes as an Indicator for Nitrogen Losses and Basis for Improved Management. Biogeosciences 2012, 9, 5303-5321. [CrossRef]

28. Galloway, J.N.; Cowling, E.B. Reactive nitrogen and the world: 200 years of change. Ambio 2002, 31, 64-71. [CrossRef] [PubMed]

29. Howarth, R.W.; Boyer, E.W.; Pabich, W.J.; Galloway, J.N. Nitrogen use in the United State from 1961-2000 and potential future trends. Ambio 2002, 31, 88-96. [CrossRef] [PubMed]

30. Isermann, K.; Isermann, R. Policy scenarios: Impacts of EU and national legislation on nutrient dynamics in river basins and oceans. In Plant Nutrition for Food Security, Human Health and Environmental Protection; Li, C.J., Zhang, F.S., Dobermann, A., Hinsinger, P., Lambers, H., Li, X.L., Marschner, P., Maene, L., McGrath, S., Oenema, O., Eds.; Tsinghua University Press: Beijing, China, 2005; pp. 1150-1151.

31. Lassaletta, L.; Billen, G.; Grizzetti, B.; Anglade, J.; Garnier, J. 50 year trends in nitrogen use efficiency of world cropping systems: The relationship between yield and nitrogen input to cropland. Environ. Res. Lett. 2014, 9, 105011. [CrossRef]

32. Leip, A.; Britz, W.; Weiss, F.; De Vries, W. Farm, land, and soil nitrogen budgets for agriculture in Europe calculated with CAPRI. Environ. Pollut. 2011, 159, 3243-3253. [CrossRef] [PubMed]

33. Ma, L.; Ma, W.Q.; Velthof, G.L.; Wang, F.H.; Qin, W.; Zhang, F.S.; Oenema, O. Modeling nutrient flows in the food chain of China. J. Environ. Qual. 2012, 39, 1279-1289. [CrossRef]

34. Godinot, O.; Leterme, P.; Vertès, F.; Carof, M. Indicators to evaluate agricultural nitrogen efficiency of the 27 member states of the European Union. Ecol. Indic. 2016, 66, 612-622. [CrossRef]

35. Oenema, O.; Kros, H.; De Vries, W. Approaches and Uncertainties in Nutrient Budgets: Implications for Nutrient Management and Environmental Policies. Eur. J. Agron. 2003, 20, 3-16. [CrossRef] 
36. Shindo, J.; Okamoto, K.; Kawashim, H. A model-based estimation of nitrogen flow in the food production-supply system and its environmental effects in East Asia. Ecol. Model. 2003, 169, 197-212. [CrossRef]

37. Shindo, J.; Okamoto, K.; Kawashima, H. Prediction of the environmental effects of excess nitrogen caused by in- creasing food demand with rapid economic growth in eastern Asian countries, 1961-2020. Ecol. Model. 2006, 193, 703-720. [CrossRef]

38. Grizzetti, B.; Bouraoui, F.; Aloe, A. Changes of nitrogen and phosphorus loads to European seas. Glob. Chang. Biol. 2012, 18, 769-782. [CrossRef]

39. Gustavsson, J.; Cederberg, C.; Sonesson, U.; van Otterdijk, R.; Meybeck, A. Global Food Losses and Food Waste; Food and Agriculture Organization of the United Nations: Rome, Italy, 2011; Available online: http:/ / www.fao.org/fleadmin/user_upload/ags/publications/GFL_web.pdf (accessed on 6 November 2013).

40. Parfitt, J.; Barthel, M.; Macnaughton, S. Food waste within food supply chains: Quantification and potential for change to 2050. Philos. Trans. R. Soc. B 2010, 365, 3065-3081. [CrossRef] [PubMed]

41. Organisation for Economic Co-operation and Development (OECD). Environmental Indicators for Agriculture; Organisation for Economic Co-operation and Development: Paris, France, 2001.

42. Payraudeau, S.; van der Werf, H.M.G. Environmental Impact Assessment for a Farming Region: A Review of Methods. Agric. Ecosyst. Environ. 2005, 107, 1-19. [CrossRef]

43. Petit, O.; Corcos, B.; O'Connor, M. Appropriation Sociale du Problème de Gestion Durable de la Nappe de Beauce. Programme Inter-Institutionnel de Recherches et d'Études en Économie de l'Environnement (PIREE); Universitè de Versailles-Saint Quentin en Yvelines: Guyancourt, France, 2001; p. 90.

44. Isermann, K.; Isermann, R. Food production and consumption in Germany: $\mathrm{N}$ flows and $\mathrm{N}$ emissions. Nutr. Cycl. Agroecosyst. 1998, 52, 289-301. [CrossRef]

45. Westhoek, H.; Lesschen, J.P.; Leip, A.; Rood, T.; Wagner, S.; De Marco, A.; Murphy-Bokern, D.; Pallière, C.; Howard, C.M.; Oenema, O.; et al. Nitrogen on the Table: The Influence of Food Choices on Nitrogen Emissions and the European Environment; European Nitrogen Assessment Special Report on Nitrogen and Food; Centre for Ecology \& Hydrology: Edinburgh, UK, 2015.

46. Bouwman, A.F.; Boumans, L.J.M.; Batjes, N.H. Modeling global annual $\mathrm{N}_{2} \mathrm{O}$ and $\mathrm{NO}$ emissions from fertilized fields. Glob. Biogeochem. Cycles 2002, 16, 28-1-28-9. [CrossRef]

47. Simpson, D.; Aas, W.; Bartnicki, J.; Berge, H.; Bleeker, A.; Cornelis, C.; Franciscus, D.; Tony, D.; Erisman, J.W.; Fagerli, H.; et al. Atmospheric transport and deposition of nitrogen in Europe. In The European Nitrogen Assessment; Sutton, M.A., Howard, C.M., Erisman, J.W., Billen, G., Bleeker, A., Grennfelt, P., van Grinsven, H., Grizzetti, B., Eds.; Cambridge University Press: Cambridge, UK, 2011.

48. Röell, C.; Erisman, J.W. Kwantificeren van de stikstofstromen in Nederland. Milieu 2011, 17, $23-26$.

49. World Health Organization (WHO). Protein and Amino Acid Requirements in Human Nutrition: Report of a Joint FAO/WHO/UNU Expert Consultation (WHO Technical Report Series 935); WHO: Geneva, Switzerland, 2007.

50. Oita, A.; Malik, A.; Kanemoto, K.; Geschke, A.; Nishijima, S.; Lenzen, M. Substantial nitrogen pollution embedded in international trade. Nat. Geosci. 2016, 9, 111-115. [CrossRef]

51. Van Der Werf, H.M.G.; Petit, J. Evaluation of the environmental impact of agriculture at the farm level: A comparison and analysis of 12 indicator-based models. Agric. Ecosyst. Environ. 2001, 93, 131-145. [CrossRef]

(C) 2018 by the authors. Licensee MDPI, Basel, Switzerland. This article is an open access article distributed under the terms and conditions of the Creative Commons Attribution (CC BY) license (http://creativecommons.org/licenses/by/4.0/). 